\title{
Labor Monopsony and the Limits of the Law
}

\author{
Suresh Naidu \& Eric A. Posner ${ }^{\mathrm{i}}$
}

May 4, 2021

\begin{abstract}
$\underline{\text { Abstract. }}$ Recent literature has suggested that antitrust regulation is an appropriate response to labor market monopsony. This article qualifies the primacy of antitrust by arguing that a significant degree of labor market power is "frictional," that is, without artificial barriers to entry or excessive concentration of employment. If monopsony is pervasive under conditions of laissez-faire, antitrust is likely to play only a partial role in remedying it, and other legal and policy instruments to intervene in the labor market will be required.
\end{abstract}

$\underline{\text { Introduction }}$

doi:10.3368/jhr.monopsony.0219-10030R1

This open access article is distributed under the terms of the CC-BY-NC-ND license

(http://creativecommons.org/licenses/by-nc-nd/4.0) and is freely available online at: http://jhr.uwpress.org 
A growing body of empirical literature indicates that labor market monopsony is widespread, and that it is depressing wages. A natural response is to encourage regulators, courts, and legislatures to strengthen antitrust enforcement as applied to labor markets. But there are strong reasons for believing that antitrust enforcement will be insufficient for countering labor market power. Antitrust enforcement can target mergers and anticompetitive behavior like nopoaching agreements, but a great deal of monopsony power is due to factors outside the reach of antitrust.

Imperfect competition regularly appears in product markets but, as a rough approximation, the institutional and social constraints on exchange of products are relatively limited, while the constraints on exchange of labor are significant and inherent in the way labor is traded. As a result of institutional constraints on the exchange of labor, a significant degree of monopsony power is held even without barriers to entry or collusion.

In this paper, we argue that even labor markets unaffected by the traditional markers of anti-competitive markets are rife with monopsony. We begin by surveying economic models of monopsonistic competition and then present some quantitative evidence that monopsony power is present even in putatively thick labor markets. We argue that pervasive monopsony implies policies well beyond the orbit of what is understood as antitrust, and we categorize these into polices that make the labor-supply constraint more elastic (e.g. antitrust or other pro-competitive policies), those that restrain firms wage-setting power via wage or benefit mandates (e.g. the minimum wage, wage boards, mandated benefits, or unions), and those that allow monopsony 
power to persist and be used by employers, but attempt to rectify the inefficiencies with other instruments (e.g. EITC or wage subsidies).

Besides paying a wage, jobs are bundles of idiosyncratic costs and amenities, for example, relationships with coworkers/managers or commute times, that are valued differently by different workers. Most workers do not obtain much experience shopping for jobs, and so mental representations of job values ("decision utility") may be particularly noisy (Woodford 2019). Further, the next best alternative of a worker often depends on the possibility of an outside offer, which in turn depends on social networks interacting with idiosyncratic labor requirements of other firms (Granovetter 1974; Caldwell and Harmon 2019). This creates monopsony power when these tastes and outside options are private information of the worker, as firms must post a single wage, and will rationally be willing to lose some workers in order to pay lower wages to others. Further, perhaps due to custom, firms tend not to actively poach already employed workers, outside of extremely high skill industries. In contrast to ubiquitous advertisements and sales experienced in the product market, there is comparatively little in the way of active competition for workers.

The closest analogy to the issues in the labor market comes not from product markets, but from housing markets, where there are potentially many sellers and yet each property faces a downward sloping demand curve due to search frictions and idiosyncratic consumer tastes over each property. Arnott and Igarashi (2000) and Arnott (1989) makes this analogy formal in a number of papers, building on search models and differentiated tastes in order to incorporate market power into rental and housing markets (and explicitly drawing the analogy to labor 
markets!). Little empirical work has followed up on this, but a recent paper by Watson and Ziv (2019) applies more traditional IO tools to estimate the degree of housing market power in Manhattan, finding markups that are $20 \%$ of rent. They further find that little of this markup can be explained by concentration, and conclude that horizontal differentiation generates the bulk of the observed market power, similarly to our conclusions. A difference between housing and employment is that houses are durable goods that can be resold and as such are intertemporally competing with themselves, which could curb the exercise of market power as in Coase (1972).

It is commonly claimed that "labor is not a commodity." Indeed this language is explicit in the text of the Clayton Act: "the labor of a human being is not a commodity or article of commerce," exempting unions from antitrust enforcement. ${ }^{\text {ii }}$ This claim is also prima facie false, in that most people sell their labor on a market in exchange for a wage. But the claim expresses an intuition that the buying and selling of labor is different from exchange of other commodities. It is unclear if labor is different from all other commodities, but it is certainly the case that various contracting frictions (for example, the impossibility of committing to staying with an employer, which is reflected in the law) make the market for labor different from the standard price-taking, homogenous commodity case.

As a result of the complexity of labor markets, the problem of labor monopsony was overlooked in labor economics until about 20 years ago despite the development of a vast parallel literature in industrial organization, and the earlier focus on power imbalances in the labor market by Adam Smith, John Stuart Mill, and Karl Marx. It is unclear why economists stopped giving attention to market power in labor markets, but a possible reason is the rise of 
unions which seemed to offer a solution to the problem of labor market power while also raising other questions for economic study. But the steady decline of unions, which dates back to the 1950s, did not revive interest in labor market power, possibly as a consequence of the widespread belief among economists that all markets (including labor markets) were basically competitive in the long run (Stigler 1942).

On the legal front, we see a similar story. The Sherman Act of 1890 did not distinguish labor and product markets and was understood at the time to apply to both types of market. Yet from the start most antitrust enforcement was targeted at producers rather than employers. In the 130 years since the Sherman Act, the case reports have overflowed with product market cases but only a handful of labor market cases, and these involve only the most explicit forms of anticompetitive behavior, like no-poaching agreements.

What can be done? We explore the possibilities and limitations of greater antitrust enforcement against labor monopsonists, and conclude that, while greater enforcement is advisable, it would be inadequate for addressing the problem. We then explore other legal approaches to problems of market power in labor markets, including wage regulation, "amenity regulation," legal support for unions, and mandates and subsidies for desirable employment features. Our takeaway is that antitrust regulation, while required to combat egregious anticompetitive practices in the labor market, is a poor substitute for traditional labor and employment law, and more extensive labor market intervention is required to combat the natural monopsonies in the labor market. 
1. Why Jobs Are Not Like Widgets: Markets for Labor Versus Markets for Commodities

Our argument begins with an empirical claim about laissez-faire labor markets: they are naturally monopsonistically competitive. This implies that market power is pervasive, and not due to artificial limits on competition nor excessive concentration. The general presence of labor market power was recognized by Joan Robinson, who wrote that:

\footnotetext{
The supply of labour to an individual firm might be limited...there might be a certain number of workers in the neighborhood and to attract those from further afield it may be necessary to pay a wage equal to what they can earn near home plus their fares to and fro, or there may be workers attached to the firm by preference or custom and to attract others it may be necessary to pay a higher wage. Or ignorance may prevent workers from moving from one firm to another in response to differences in the wages offered by the different firms. (Robinson 1933 (1969, ed., p. 296))
}

Note the absence of anything like "concentration" in Robinson's formulation; she does not mention the lack of other employers in the area as a source of upwards sloping labor supply. Institutionalist American labor economists readily took the notion of upward sloping labor supply on board, again without any reference to concentration. In a 1946 article in the Quarterly Journal of Economics entitled "The Supply of Labor to the Firm” Lloyd Reynolds wrote:

The assumption that workers are fully informed and completely responsive to wage differences may be altered in three main ways. It may be assumed that workers are 
ignorant of the wages paid by other employers, or that they are perfectly informed concerning wages but are deterred from changing jobs by considerations of security, or that they are perfectly informed concerning wages but differ in their evaluation of the non-base-rate components of the wage. (Reynolds 1946, p. 393)

The problem of generically upwards sloping labor supply curves facing firms, even in diffuse and putatively thick labor markets, has thus been recognized for quite a long time even if it has been ignored in recent decades.

\section{Models of Monopsonistic Competition}

In this section we briefly outline the economic models of monopsony where firms have market power despite markets being "thick"-with large numbers of employers and workers. While these are reviewed in a number of other papers, we focus on their most recent variants and their implications for antitrust. These models formally capture the forces generating monopsony identified by Robinson and Reynolds, and do not rely on concentration as an important determinant of monopsony power. .ii $^{\text {ii }}$

The paradigm of antitrust is focused on market structures with few firms. Indeed, the primary diagnostic statistics are measures of concentration, for example, market share of the top four or five firms and Herfindahl measures of concentration (often motivated by underlying Cournot models of imperfect competition among a small number of firms). We first present a simple variant of this type of model here. 
The Cournot model is the original workhorse model of industrial organization, where $n$ firms take a demand curve as given and choose quantities produced. This model is simple to recast as an oligopsonistic model where employers choose employment facing an increasing, inverse labor supply curve $w($.$) , as in Naidu, Nyarko, and Wang (2016) among many others. In a$ simple variant of this model with constant marginal productivity $p_{i}$, firms choose $L_{i}$ to maximize:

$$
\left(p_{i}-w\left(\sum_{i=1}^{n} L_{i}\right)\right) L_{i}
$$

Under a sufficiently convex $w()$ function, this game will have an equilibrium solution which motivates the Herfindahl $\left(=\sum_{i}^{n} s_{i}^{2}\right.$, where $s_{i}=\frac{L_{i}}{\sum_{i=1}^{n} L_{i}}$ is the share of employment at firm $\left.i\right)$ measure of concentration, and expresses the markdown as the ratio between the Herfindahl index and the aggregate labor supply elasticity to the labor market: $\eta^{a g g}=\frac{w}{w^{\prime}(L) L}$, where $L=\sum_{i=1}^{n} L_{i}$

$$
\frac{\left(p_{i}-w\right)}{w}=\frac{\sum_{i}^{n} s_{i}^{2}}{\eta^{a g g}}=\frac{H}{\eta^{a g g}}
$$

In this model, wages will fall as local labor market concentration increases, holding productivity and the aggregate labor supply elasticity constant, a result that has been found in a number of recent papers (Benmelech et al. 2018; Azar et al. 2017; Rinz 2018).

One difference between this literature and the previous literature on concentration is which "quantity" measure is appropriate. A more general form of the Cournot model, where employers are not choosing employment, but rather some other strategic variable such as vacancies or recruitment intensity or retention efforts, could be warranted. ${ }^{\text {iv }}$ Below we discuss 
measures of concentration that account for likely flows of workers between firms, which synthesize a number of sources of monopsony.

But even in these general models, market power falls as the number of firms, $n$, increases and approaches the perfectly competitive limit. The interpretation of the empirical relationship may be quite sensitive to how markets are defined, as it depends on which aggregate labor supply elasticity is used. More germane to our purposes here, the Cournot model also shows that market power cannot persist in the long run as more and more firms enter, attracted by positive profit. If there are no fixed costs of entry, for example, long-run markdowns are 0.

The Cournot model can help us compare product markets to labor markets. The literature on concentration in labor markets has pointed out that, for reasonable definitions of labor market boundaries, labor markets are much more concentrated than product markets (Marinescu and Hovenkamp 2018), with HHIs well exceeding the antitrust thresholds. Further, the scope for monopsony power in labor markets is larger even holding the degree of concentration fixed: product market demand elasticities from the trade literature vary from 1.2 (footwear) to 17 (crude oil), with a median product elasticity of 4.5 (Broda and Weinstein 2006), while aggregate labor supply elasticities are generally between .1 and 1 (Chetty 2012). Within a Cournot model, these would imply that the same HHI would result in a larger markdown in the labor market than the corresponding markup in the product market.

The Cournot model has the virtue of being extendable and flexible. Naidu, Nyarko and Wang (2016) use the average number of other firms workers transition to as a measure of the 
effective competition in a Cournot model. Krueger and Ashenfelter (2018) expand the Cournot model to accommodate anti-competitive practices. Franchise no-poaching agreements essentially reduce the number of competitors in the labor market, increasing "effective concentration." We discuss more of these extensions below. Arnold (2020) extends the Cournot model to flexibly accommodate flows between markets and model the effects of mergers. ${ }^{\mathrm{v}}$

While concentration is a clear empirical determinant of labor market monopsony, it has not been the traditional focus of labor economists interested in monopsony. Instead, labor economists have focused on models of imperfect competition that have many firms and many workers, yet still deliver upward-sloping labor supply curves to each firm. When market power is generated by forces emphasized in these thick-market models, traditional antitrust remedies may be inadequate.

There are two categories of these monopsonistically competitive models: the first, and traditionally more emphasized in labor and macroeconomics, is based on search theory, where workers must actively look for employers. The second, while applied much more recently to labor market problems, is extensively developed in industrial organization, and emphasizes product (in this case job) differentiation and heterogeneous tastes for jobs or costs of switching.

\section{$\underline{\text { Search Frictions }}$}

As Robinson and Reynolds both pointed out, workers might not know about all the jobs available, and this simple idea has given rise to a vast literature on search in labor markets (see 
Rogerson, Shimer and Wright (2005) for a review). Stigler (1961) developed the original model of job search, where workers sample from the distribution of jobs. This model generated a number of predictions, only some of which were borne out in the data. This idea was turned into a dynamic model of sequential search by McCall (1970), where workers would sample repeatedly from the distribution of jobs until a job was located. Rothschild (1973) criticized much of the search literature by pointing out that the distribution of offered wages was taken as exogenous, and that there was no underlying model of firm optimization that delivered dispersion in the set of offered wages that motivated worker search.

Diamond's (1971) paper, allowing both firm optimization and identical searching workers, showed that when a model of costly worker search was integrated with a model of identical firms choosing wages, the unique equilibrium was complete monopsony, where all firms offered workers exactly their outside option, and no worker searched. In this equilibrium, no firm deviates by paying a higher wage because no worker is searching (so they get no additional workers), and no worker bothers searching because all firms are offering identical wages.

This model is somewhat extreme, and substantial progress was made by Burdett and Mortensen (1998) in extending the search model to include on-the-job search. In this variant of the search model, workers continue to search while working, which gives firms an incentive to try and poach workers from each other. Strikingly, in this model the unique equilibrium, despite a large number of identical workers and firms, has wage dispersion, where each firm pays a 
different wage, trading off losing workers to firms paying more with making higher profits on each worker that stays.

The key parameter measuring the degree of labor market competition in this model is the ratio, $\kappa$, of the job-offer arrival rate to the (exogenous) job destruction rate. $\kappa$ measures the rate at which searching workers encounter offers relative to the rate at which they lose jobs; when it is high, the labor market is tight, and indeed, as this ratio approaches infinity, the wage dispersion collapses and the model is identical to Bertrand competition, with all workers paid their productivity $p$. As $\kappa$ approaches 0 , the wage dispersion again collapses and the model collapses to the Diamond model described above, with all workers paid their reservation wage $b$.

Artifices that make it difficult to poach workers who are already employed naturally reduce $\kappa$. Naidu (2010) and Krueger and Ashenfelter (2018) model the effect of anti-enticement laws and no-poaching agreements, respectively, as falls in the job offer arrival rate.

The Burdett-Mortensen model has become a standard workhorse model in labor economics and macroeconomics. Quantitative and structural variants of this model have been fit to explain the job ladder over the business cycle, the fall in the labor share, wage inequality, minimum wage effects on employment and inequality, and empirical patterns of tenure and experience wage profiles.

\section{$\underline{\text { Job Differentiation }}$}


Bertrand (1883), while reviewing Cournot, pointed out that firms are more likely to compete on prices than quantity. In Bertrand's famous model, even a single competitor is enough to discipline a firm's exercise of market power. The labor market analogue of Bertrand competition has firms maximizing:

$$
\left(p_{i}-w_{i}\right) L_{i}\left(w_{i}, w_{1} \ldots w_{i-1}, w_{i+1}, w_{n}\right)
$$

In the classical Bertrand model with heterogeneous firms, firms can hire unlimited workers, and if firms have different productivities, all workers will be employed by the most productive firm, which will pay the productivity of the second most productive firm. Concentration in this model is uninformative, as there will be only one firm employing any workers, and yet that firm has no market power (if the firm lowered the wage even slightly it would lose all its workers immediately to a new entrant). The contestability of a market by new entrants is what leads many economists to dismiss measures of concentration as proxies for market power.

However, this model of workers choosing jobs considering only the highest wage is unrealistic. Firms are places to work, and consist of a high-dimensional set of amenities, whose valuations will vary wildly in a given population of workers. A large literature in product competition has extended the Bertrand model to include models of product differentiation, where firms still compete on price but products are imperfect substitutes for each other.

Differentiation can occur along a wide variety of characteristics, including spatial location, product characteristics, and product quality. Similarly, jobs are also highly 
differentiated, both spatially (e.g., location of employer and hence commute times) and along bundles of amenities, both tangible (e.g., benefits, job safety) and less tangible (relationships with managers and coworkers).

Jobs are not only differentiated along these various dimensions, but workers perceive and value these dimensions differently. Note that even jobs that seem quite standardized (e.g. cashier) in terms of the productive tasks, so that there is little firm-specific human capital, can be valued idiosyncratically by workers due to particular tastes over commutes and workplace relationships. In models of random utility, workers have idiosyncratic utility over different jobs. Crucially, firms may not be able to observe this taste heterogeneity, and internal constraints on wage discrimination (e.g., internal equity) may force firms to post only one wage per job. This restriction is what makes labor market power inefficient: if firms could perfectly tailor the wage to each worker's taste for working at that firm, so-called perfect wage discrimination, there could still be market power, but it would not be inefficient, even as all surplus is extracted by the employer.

Firms thus know there are some workers who would work for the firm at a lower wage, but do not know which workers those are. So the profit-maximizing strategy is to pay below marginal product, accepting the loss of the workers who prefer working somewhere else in exchange for the profits made off those workers who stay. 
These models have a long tradition on the product market side, being workhorse models in quantitative marketing research as well as being the foundation for much of demand system estimation in industrial organization. Anderson, De Palma, and Thisse (1992) provide a survey of product differentiation models, while Card, Cardoso, Kline, and Heining (2018) adapt a variant of multinomial choice to model monopsony in the labor market.

Gabaix et al. (2016) show that there is a subtle relationship between competition and the degree of price distortion in these random utility models. Depending on the shape of the distribution of the random utility terms, markups can stay positive even as the number of firms increases; indeed, if the distribution is fat-tailed enough, markdowns can grow without bound even as the number of firms approaches infinity! This result shows that simplistic measures of concentration or number of firms do not necessarily map into more or less wage (or price) distortion.

Finally, just as workers have distinct preferences over jobs, firms have different preferences over workers. This gives the market a two-sided matching characteristic, naturally implying thinner markets than when only one side has preferences over the other side. The set of workers one firm prefers may be small, and the set of workers that prefer that firm is even smaller. This "differentiation-squared" may exacerbate market power in labor markets relative to product markets.

Azevedo (2014) shows how market power can operate in a model of two-sided matching even when matches are optimal. In this model firms have some market power (even assuming 
wages are fixed), and reduce their hiring in order to shed marginal workers, who then get employed by another firm, who in turn sheds workers that may be supra-marginal for the initial firm. These "rejection chains" give firms with labor market power an incentive to set quantities too low in order to obtain more productive workers, even if they cannot change the wage. Caldwell and Danieli (2018) propose a 2-sided matching model of the labor market and use it to calculate an Outside Options Index (OOI), which is the inverse of worker-specific Herfindahl index over likely other jobs. If a worker with characteristics $\mathrm{X}$ is likely to be employed at many firms, the OOI is high. Monopsony in this model could manifest as many workers with different OOI nonetheless being paid the same wage within a firm.

A related, but more sociological source of taste-based monopsony is endogenous worker loyalty. Bowles and Gintis (1976) emphasized the role of endogenous worker preferences in maintaining employer profits. A large literature in sociology, perhaps beginning with Michael Burawoy's 1979 Manufacturing Consent: Changes in the Labor Process Under Monopoly Capitalism, argued that employers engineer work environments so as to maximize worker productivity and minimize conflict with management. Workers also develop attachments to coworkers (Fantasia 1995), employers, and in service-sector industries, even customers (Hochschild 1983). While this literature has not considered the effects of these types of attachments on quit behavior, job search, and labor market competition, it is plausible to believe that workers may be exploited due to their personal or emotional attachments to the job and to working. Employers may try to invest in increasing these attachments by fostering corporate loyalty or specializing the content of training programs. 
When firms have product market power, advertising is quite profitable, as profits are positive on every additional unit sold. A similar logic is true for monopsonists, as monopsonists suffer losses of profits from every additional quit. But employers get eight hours a day of free advertising to their employees, and "corporate culture" together with "employee loyalty programs" may be inefficiently high as companies invest in these devices to cultivate loyal workers who are wage inelastic, rather than raising wages to prevent quits. There is very little in the way of compelling evidence on the causal effect of loyalty on wages, however (Masakure (2016) is one such attempt, but the exclusion restriction, that religiosity is a valid instrument for loyalty, is dubious).

Workers' social preferences for fairness may also militate against wage discrimination, even when employers have accurate information about worker's tastes and outside options. A considerable amount of evidence (Card et al. 2018, Fehr and Falk 1999; Breza et al. 2019; Dube et al. 2018) has shown that workers react negatively to disequalizing pay schemes, and this may exacerbate the inefficiencies due to monopsony, even while preventing employers from fully exploiting their market power (via wage discrimination of workers).

\section{$\underline{\text { Hybrid Models and Alternative Definitions of Concentration }}$}

The recent literature on monopsony has grown quickly, and there are a number of recent models that are hybrids of the three models above. Berger, Herkenhoff, and Mongey (2019) construct a nested logit model where workers first choose a labor market, then choose a firm within that labor market. The authors choose utility functions and random utility shocks that 
yield a nested CES formulation of the labor supply decision of a representative household. This model is a case of our reduced-form decomposition below, where the labor supply elasticity facing the firm can be decomposed into a firm-specific component (based on differentiation) and a market component (based on concentration). The model delivers a wage-share variant of the Herfindahl-Hirshman Index (HHI) that combines the monopsonistic competition dimension of monopsony with the concentration dimension.

Arnold (2020) uses the Longitudinal Employer Household Dynamics (LEHD) survey, a matched employer-employee dataset, to look at the effect of mergers on wages. In his theoretical model, rather than defining concentration with respect to a fixed industry within a commuting zone, he uses job-to-job flows across industries to construct "shares" where a firm's employment is divided by flow-weighted employment of all other firms in the commuting zone. This measure of concentration has the advantage of not requiring one to take a stand on which administrative boundary (e.g. occupation or 4-digit industry) is relevant for defining a labor market. Arnold shows that this measure is generally highly correlated with commuting zone $\mathrm{X}$ industry $\mathrm{HHI}$ indices.

Finally, a pair of papers relate concentration to wages via bargaining rather than monopsony. Schubert, Stansbury, and Taska (2020) use Burning Glass data to measure concentration but add an outside option that depends on occupational transition probabilities. In their model wages are set by bargaining rather than wage posting. Another recent paper by Jarosch, Nimczik, and Sorkin (2019) develop a model with search and bargaining where the worker's outside option depends on the concentration of firms. Firms in this model commit to 
never renegotiating with a worker after the first match, and this means that large firms have a bargaining advantage because workers will be more likely to encounter offers from that large firm in the future; never being able to contract with a large firm again makes a worker quite willing to take whatever offer that firm is offering. Hence highly concentrated labor markets have workers with low outside options and thus lower wages. While technically the assumption of efficient bargaining makes this not a model of monopsony, this model will also generate a negative relationship between concentration and wages.

As far as we are aware, there is no paper that combines all three of search, job differentiation, and concentration into a single model of monopsony. There is some structural work (Flinn and Mullins 2019) that endogenizes the choice between wage-posting and Nash bargaining, and integrating this into the empirical literature seems like a promising direction for future work.

Which measure of concentration is to be preferred? Bassier et al. (this volume) show correlations between a large number of $\mathrm{HHI}$ indices (e.g. flows adjusted, payroll vs new recruits vs employment shares, industry vs geography) and firm-specific labor supply elasticities, with ambiguous results. While HHI indices are all highly correlated with each other, they are only weakly correlated with the firm-specific residual elasticities. This suggests that more finegrained measures of concentration ought to be constructed at the firm level, while allowing for variation in firm wages even in the limiting case of no strategic interaction. This perhaps could be done by synthesizing the Caldwell and Danieli measure (or a firm variant of Arnold 2020) 
with the Berger et al. measure, combining flows across firms with shares of payroll rather than employment.

\section{Evidence for Monopsonistic Competition.}

What is the evidence for monopsonistic competition in in the labor market? Direct estimates of monopsony power that are obtained in thick labor markets are the most compelling evidence. For example, the minimum wage results that motivated the original monopsony model were obtained in thick labor markets. The most credible evidence is provided by the few randomized controlled experiments where wages are randomized for identical jobs in markets with many wage-setters and little in the way of barriers to mobility. Sydnee Caldwell and Emily Oehlsen (2018) randomize wages for Uber drivers, including those that also drive for Lyft. They examine the rate at which drivers switch, and find a surprisingly low elasticity of between 4 and 5, given that workers literally just have to switch apps on their phone. Arin Dube and coauthors (Dube et al. 2018a) experimentally vary wages for an identical task and find substantial monopsony power even on (putatively thick) Amazon Mechanical Turk, and Dube et al. (2018b) find a moderate quit elasticity (in response to wage changes induced by discontinuities in the national pay setting scheme in a large low-wage retailer. Dube, Manning, and Naidu (2019) bound the labor supply elasticity facing the firm in low-wage labor markets using the extent of bunching at $\$ 10.00$. Bassier, Dube and Naidu (2019) use firm fixed effects to isolate the firm component of worker wages in matched worker-firm Oregon data and use this to estimate a labor supply elasticity between 2.5 and 3 . They also find that this elasticity does not vary very much by employer concentration. 
Other direct estimates include evidence on wage increases from small firms that exogenously receive shocks to the firm-specific marginal product of their labor. In the U.S., these shocks include patents in small firms (as in Kline, Zidar, Petkova, and Williams 2019), fiscal stimulus shocks from ARRA contracts (Cho 2019), and wins in procurement auctions (Kroft et al. 2020). Goolsbee and Syverson (2019) use shocks to admissions at universities to show monopsony power in the tenure-track academic labor market, which is generally national in scope. By dividing the (log) employment response to the shock by the implied rent-sharing elasticity (the log wage effect of the shock), an estimate of the residual labor supply elasticity is obtained. Evidence in this vein against monopsonistic competition is provided by Matsudaira (2014), who finds that exogenous increases in nurse aide employment resulted in no increase in wages, suggesting perfectly elastic supply curves.

Arnold (2020) finds negative effects of concentration driven by mergers in thin labor markets but concludes that mergers and concentration are unlikely to be a big contributor to overall wage stagnation, with concentration resulting in wages only $5 \%$ below a fully competitive benchmark. This relatively small concentration markdown is difficult to reconcile with the rent-sharing elasticities or firm-specific labor supply elasticities unless there is a significant degree of non-concentration-based labor-market power.

There is also evidence from structural papers that estimate both differentiation and concentration in the same model. While dependent on functional form assumptions, these papers 
show that there remains a significant amount of "pure" horizontal differentiation. Berger et al. (2019) recover a within-market substitutability of 5.4, and a recent paper by Azar, Berry, and Marinescu (2019) who estimate a structural labor supply model on vacancy data and also recover a pure differentiation elasticity of around 5.8.

A simple way to reconcile these estimates is to note that monopsony is not the only constraint facing firms. Firms must also use wages to provide incentives, mitigate adverse selection, and induce loyalty and reciprocity. Rent-sharing elasticities reflect all of these other constraints on firm wage-setting, not simply the labor supply constraint. For example, in efficiency wage models combined with monopsony, the wage is potentially much higher than the pure monopsony wage (although employment is potentially much lower and would be characterized by job rationing). This is plausibly what is happening in Matsudaira's estimates, where wages are regressed on shocks to employment. It also cautions against taking the ratio of employment to wage responses to a shock as a clean estimate of the labor supply elasticity, as it could for example reflect the shape of monitoring costs (Rebitzer and Taylor 1995). While the IV estimate does reveal a mean residual supply elasticity, one could imagine diverse rent-sharing mechanisms inducing heterogeneity in the estimates.

Where labor markets appear governed by "the law of one price," it may be due to the effect of social norms and convention rather than competition. Dube, Giuliano, and Leonard (2018) show that the appearance of high quit rates in response to wage changes is driven more by comparisons across workers than sensitivity to the own wage. That is, when all workers are given the same wage increase, the quit rate falls by only a little bit, but when some workers are 
granted raises while others at the same store are not, the latter are much more likely to quit. Breza, Kaur, and Krishnaswamy (2018), a paper tellingly titled "Scabs", also show that rural village markets exhibit substantial monopsony power. They randomize wages to workers in private and in public, and find that workers are willing to take jobs at the same rate even at a $10 \%$ wage cut in private, but are unwilling to do so in public. The appearance of an extremely elastic labor supply facing the employer/experimenter is driven by social sanctions against accepting low wages in public. A possible explanation is that workers recognize that they are collectively harmed if they compete over wages and employ social sanctions to restrict competition, a practice that is of course formalized by unionization but can occur informally as well. As is well known, it is difficult to infer much about market structure from dispersion alone, as both competition and collusion can result in uniform wages; in labor markets the prevalence of social norms around pay-setting may exacerbate this difficulty.

\section{Implications for Antitrust Law}

Antitrust law prohibits certain types of actions by firms to accumulate and exercise market power. Typically, antitrust law has been applied to anticompetitive actions in product markets, blocking firms from agreeing to fix prices or quantities, divide territories, and in other ways reduce competition among themselves or exclude competition from entrants. Antitrust law also prohibits monopolies or firms with large market shares to tie up their customers so as to exclude competition, to extend their monopolies into new markets, and related actions. Mergers between firms are also prohibited when they resulted in significantly increased market concentration that cannot be justified with efficiencies. 
These legal constraints apply in theory to labor markets as well, although litigation is far less frequent. Agreements to fix wages, not to poach employees, exchange salary information so as to reduce the risk of poaching, and related agreements, are illegal. Monopsonists may be also be liable if they use their labor market power to prevent rival employers from entering the market (for example, by tying up employees with noncompetes) or extend their monopsony power to the employment market - though cases that address these behaviors are virtually nonexistent. The U.S. government has acknowledged recently that mergers should be reviewed for their labor market effects as well as their product market effects.

As a rough approximation (with exceptions discussed later), antitrust law addresses the problem of market concentration. And while concentration in labor markets is significant, the models surveyed earlier suggest that considerable monopsony power can persist even in large, non-concentrated labor markets with many employers. This makes antitrust law an unwieldy device to handle labor market monopsony. While concentration can exacerbate the monopsony originating in either search or differentiation, it is by itself not a sufficient metric for market power. Antitrust is set up to police anticompetitive behavior, including excessive concentration and egregious price-fixing behaviors. But if market power is generated by search frictions or heterogeneous, privately known costs and preferences, then antitrust law can do little.

However, this does not mean that antitrust enforcement of labor markets should be abandoned as fruitless. In previous work we have outlined detailed applications of antitrust to labor market power (Naidu et al. 2018). Indeed, in this section we further argue that antitrust 
enforcement has been shamefully neglected, and should be strengthened because it can do some good. But as we will further show, stronger and more tailored policy instruments are needed to make significant progress on the problem of labor monopsony.

The evidence of neglect is substantial. Statistical and anecdotal evidence suggests that mergers and consolidation over the last several decades have led to greater labor market concentration and wage suppression in affected labor markets. Debates remain as to how to define labor markets, and whether concentration has increased on average across labor markets over time varies depending on labor market definition. Across a variety of definitions, however, labor market concentration appears robustly negatively correlated with wages, and this result has been found in high quality studies (Azar et al. 2017; Benmelech et al 2018; Rinz 2018; Hershbein, Malacusa, and Yeh 2019). Firms have also been caught engaging in classic horizontal arrangements, such as no-poaching agreements, that suppress wages by reducing competition among employers for workers in a specific labor pool (Department of Justice 2010). It also turns out that no-poaching agreements are extremely common in franchises, and may further contribute to wage suppression in thin labor markets where a small number of franchises compete with each other while restraining competition for workers among their subordinate franchisees (Krueger and Ashenfelter 2018). Finally, concerns have been raised about the ubiquity of covenants not to compete, which have been frequently applied even to low-income workers who receive little training (Starr et al. 2019, Krueger and Posner 2018).

A further development in recent years is the rise of labor market platforms, which match customers (e.g., households) with workers (e.g., domestic care workers or cleaners). These 
platforms, we argue, tend to be natural monopsonies with significant increasing returns in employment of workers. This is because the volume of workers on the platform increases the odds of a match with a customer, which attracts customers to platform, and thus even more workers. This technological development may cause concentration to re-appear as an important source of monopsony. Below, we discuss how these platforms may be arbitraging a presumption in the law that independent contractors are not subject to market power. Ironically, the same platforms make it quite feasible for researchers to obtain experimental estimates of employer power: Caldwell and Oehlsen (2019) and Dube et al (2020) both present experimental estimates of market power by randomizing wages across Uber drivers and Amazon Mechanical Turk workers, respectively. Both find surprisingly low residual supply elasticities, despite Uber drivers being able instantly switch to Lyft on their phones and MTurk workers being able to find alternative tasks instantaneously.

Many of these trends can be traced to lax antitrust enforcement. The government has not screened mergers for labor market effects. As Figure 1 shows, private antitrust lawsuits against labor monopsonists are uncommon. Such lawsuits are risky and expensive, and face a range of legal restrictions (such as limits on class actions) and practical difficulties (such as relatively low payoffs). Employers have also realized that they can block class actions by adding arbitration clauses to employment contracts, thanks to favorable decisions by the U.S. Supreme Court. Some older legal precedents suggest that no-poaching agreements within franchises may be permissible, while in most states noncompetes are subject to only weak review under the common law and are rarely subject to sophisticated antitrust analysis (Posner 2020a). 
It is clear that more vigorous antitrust enforcement would be justified. The government should develop a procedure for reviewing mergers for their labor market effects (Naidu, Posner, and Weyl 2018; Marinescu and Hovenkamp 2018). Congress and state legislatures can and should pass laws that relax restrictions on class actions, subject noncompetes to stricter review or ban them outright, restrict no-poaching agreements within franchises, and strengthen private rights of action against firms that monposonize (Marinescu and Posner 2018).

However, these reforms are likely to have only partial impact on wage suppression. The major problem is that most of them address only the problem of labor market concentration. Stricter merger review, for example, would at best reduce the rate of further labor market concentration, and even strict merger review may not be able to stop long-term trends toward concentration caused by growing economies of scale and other factors. It is unlikely that courts would break up large labor market monopsonists under the antitrust law, and even if they did, this would not likely have much of impact, since labor market concentration is mostly a local phenomenon. And firms can locate plants in sparely populated areas in order to avoid labor market competition, although this incentive is at least partially offset by agglomeration forces making plants locate in dense localities. Antitrust law is unlikely to block such behavior because the additional jobs, even if low-paying, are on balance beneficial to the local labor force.

Limits on noncompetes also would affect only a small part of the problem. Noncompetes contribute to wage suppression in two ways. First, they increase the cost of entry into labor 
markets by rival employers, who may find it impossible to hire workers bound by noncompetes. Because employees do not internalize the labor-market cost, they will agree to noncompetes that are socially costly. Second, when noncompetes are imposed on workers without their knowledge, as sometimes seems to occur, they reduce those workers' bargaining power if they cannot obtain a lawyer or legal advice (and even then the extra cost may be prohibitive for many workers). For these two reasons, legal limits on noncompetes can be socially desirable. Indeed, one might even imagine "negative" noncompetes, or anti-anti-enticement laws—laws that give subsidies to employers who poach employees from other employers rather than hire at the entry level. These laws would increase employees' bargaining power vis-à-vis the incumbent employer, enabling them to demand a higher wage. However, noncompetes may also be justified. Firms may be reluctant to entrust workers with trade secrets or make general investments in workers unless protected by noncompetes. If noncompetes were prohibited, workers may therefore be harmed. Critics have therefore been more comfortable advocating the abolition of noncompetes only when used to bind low-skill workers (Krueger and Posner 2018; Posner 2020a).

Like in the product market case, some increased labor market monopsony has probably been caused by trade and technological factors unrelated to mergers and other types of anticompetitive behavior that can be straightforwardly targeted by antitrust law. Benmelech et al. (2018) show that exposure to Chinese trade shocks resulted in increased labor-market concentration in manufacturing, lowering wages in exposed labor markets (particularly nonunionized ones). Many tech firms, for example, owe their market dominance to network effects. It would have been quite difficult for antitrust authorities to stop Google and Facebook from achieving product market dominance because they gained most of their early market share by 
offering products and services that customers wanted. Similarly, on the labor market side, firms like Uber have exploited advances in technology that have enabled them to isolate and monitor workers, and circumvent legal protections like minimum wage laws; they have not needed to merge with other firms in order to obtain this labor market power.

But there is a further problem for labor markets that they do not share with product markets, which is that labor markets are highly fragmented—far more so than most product markets. The reason is that people are less mobile than goods, with the result that labor market areas are typically (though not always) smaller than product market areas. To understand this point, consider, for example, the merger of two big farm equipment manufacturers. The market for farm equipment is national in scope,${ }^{\mathrm{vi}}$ and hence an agency or court that evaluates the merger can focus on that single national market. To evaluate labor market effects, by contrast, one must identify the location of the factories of the two firms, which may be scattered throughout the country (or world). In some labor market areas, the merger may result in factory shutdowns, in others not. One then must evaluate all aspects of the local labor market - such as whether other employers, including employers in different industries, offer comparable jobs. And one must take into account the different types of workers in each factory—-for example, line workers and IT workers belong in different labor markets. While some product markets are fragmented in this way, the problem for labor market antitrust is that fragmentation is pervasive if not universal. Indeed, applying existing market definition tests to labor markets may conclude that the relevant market is just the firm itself! 
The boundaries of the labor market will clearly matter for both measuring monopsony as well as interpretation of the results. The boundaries of the labor market determine the relevant "aggregate" elasticity in the Cournot model. The aggregate elasticity presumably increases as the boundaries of the labor market become finer, and so if labor markets are defined too narrowly, concentration will be quite high, but the correlation with wages will be low. In practice, it seems like individual firms have plenty of market power independent of market concentration, and so this attenuation seems not to be an issue. But if concentration-based monopsony is the target of antitrust policy, then careful attention to labor market definition will have to be paid.

Next, consider the problem of search frictions. These frictions can create market power in product markets as well as labor markets. Consumers who have trouble searching for substitutes - say, for their cellphone plan because of the complexity of the product and the difficulty of comparison — are subject to product market power from sellers. But not all products are complex, or otherwise involve search frictions. A huge range of products are simple commodities — in many cases easily evaluated (like furniture), in other cases made comparable thanks to private and government market interventions that have produced standard types and grades, and resulted in disclosures like nutrition information and safety records. Even for more complex products and services, an enormous intermediary market of advisers, like Consumer Reports, have emerged to reduce the cost of search.

In contrast, search costs in labor markets are potentially large. Similar-seeming jobs often involve enormous variation. For example, the job description of a lawyer at a law firm might be "complex litigation" or "complex commercial litigation." But lawyers with this job description 
do very different things at different firms because different firms have different cases, divide tasks among litigators differently, and — of course — have different lawyers, which will affect the various interpersonal relationships that are involved in any litigation. Like in the product market case, intermediaries - headhunters - have arisen to help reduce search frictions. But these markets are themselves quite opaque. The search frictions give employers bargaining power over their workers to a far greater extent than exists in product markets. New companies like Glassdoor, which aggregate employee ratings of a variety of jobs and employers, may help reduce these search frictions.

Conventional antitrust enforcement would not address wage suppression caused by search costs or job differentiation except in unusual cases where it can be shown that firms took deliberate steps to increase search costs and job differentiation for anticompetitive purposes. Nopoaching agreements fall into this category. A no-poaching agreement does not increase labor market concentration, since the employees remain independent, but it results in wage suppression because search costs are increased: a worker fired by firm X will not be able to find a job with rival firm $\mathrm{Y}$ if the two firms entered a no-poaching agreement. But high search costs may simply be a feature of a labor market, for example, because jobs involve complex and hard-to-compare tasks.

Similar points can be made about job differentiation. This source of labor market power is, like search costs, related to the complexity of the work relationship. But search costs are the result of information asymmetries over the wages available, while job differentiation refers to variation in the preferences of workers over different types of jobs. Some law firms have highly 
intense and competitive cultures; others don't. These differences appeal to different types of lawyers. Thus, an apparently large labor market—litigators — turns out to be smaller-intense and non-intense litigators. And then there are further types of differentiation as well, like case types - some people prefer antitrust cases, and others prefer employment cases, and many law firms specialize accordingly. Here again, we can think of product-market analogies, but they are rare rather than pervasive. Some airlines differentiate themselves by offering better service and others by offering low prices. Insurance companies also offer complicated different features in insurance contracts. But there seems to be natural limits on this type of differentiation - perhaps because more complex differentiation confuses consumers. Moreover, because work is such an important part of people's life, people are naturally concerned even about minor aspects of it, whereas most products — housing is probably the only exception — add relatively little value to one's life. ${ }^{\text {vii }}$

Like search costs, job differentiation poses significant challenges to antitrust law. When employers differentiate jobs, they can nearly always claim, with considerable plausibility, that they are merely giving their workers what those workers want, or providing attractive positions to people who may be unsatisfied with their jobs at rival firms. Thus, job differentiation can easily be seen as pro-competitive.

And job differentiation may also arise naturally as firms compete for workers with different workplace tastes. It would be difficult for courts to distinguish this type of natural job differentiation from job differentiation that occurs as a conscious strategy to suppress wages. 
But antitrust law could police job differentiation by investigating the business rationale for a variety of job characteristics. A 2008 report by the Society of Human Resource Managers (Allen 2008) titled "Retaining Talent" enumerates a wide variety of HR practices for reducing turnover. We reproduce data from their Table 4 in Figure 2 below, which shows results from a survey of HR managers where they evaluate a variety of job characteristics in terms of retention efficacy as well as say whether they would offer it. Interestingly, the most efficacious (childcare) are rarely offered, presumably due to cost, while the least efficacious are the most likely to be offered (health-care benefits), consistent with employer optimization. More germane to our argument is that while many are pay-focused, many others consist of practices that could be argued to be anti-competitive, including non-compete clauses (which are rated both moderately effective, as well as somewhat likely to be offered). If the only purpose of some of these practices was to increase retention, with no net benefits to workers or customers, then arguably any of them could be an antitrust violation.

$\underline{\text { Some Anti-Antitrust Arithmetic }}$

In this section, we calibrate a model of imperfect competition that allows for both concentration and non-concentration based sources of monopsony. Concentration works via Cournot competition in quantities, with each firm's choice of quantities altering the wage that 
every other firm must pay. Non-concentration based monopsony works by allowing the wage each firm must pay to be an upwards sloping function of its own employment choice, irrespective of the employment choices of other firms. We then use existing estimates of concentration and aggregate and firm-specific labor supply elasticities, calculating how much monopsony power is "frictional" and would remain even if concentration were eliminated.

In order to implement our calibration, we need a study that both estimates the residual labor supply facing the firm, as well as concentration, and then see if concentration can be a reasonable conduct parameter given an aggregate labor supply elasticity. Many of the papers that measure labor market concentration do so in markets where it is difficult to know what the market-level labor supply elasticity is. In Chetty (2012), a lower bound is given by the aggregate market labor supply with an extensive high end of the elasticities of .5, but this is likely much too low for the labor supply elasticity to a particular market. Another estimate is given by Monte, Redding and Rossi (2018), who suggest a local employment elasticity of 1.52, although their model emphasizes heterogeneity, with elasticities between 0.5 and 2.5 .

Alex Bartik (2018) provides a more appropriate estimate of the aggregate supply elasticity to a labor market that is closer to the labor market definition of many of the papers that measure concentration. He uses trade shocks with China and the fracking boom to estimate migration elasticities into labor markets, finding significant obstacles to mobility, with moving costs to location around $20 \%$ of annual income (and between $4-5 \%$ for occupation and industry). These can be converted into labor supply elasticities using the ratio of the effect of each shock on employment to the effect on wages. Using estimates from Table 5 and Table 6 of his 2018 paper, 
we get labor supply (to the sector X commuting zone level) elasticity estimates of roughly 2.8 from both shocks.

We can then start to see why concentration cannot be the primary source of monopsony power from Webber (2015), who finds the average firm share of employment is only $9 \%$ in a county-industry, and yet he finds a firm-specific labor supply elasticity of 1.08. Taking the above values of the aggregate labor supply elasticity, this is simply too much monopsony power and too low an average firm share a of employment for concentration alone to be the source of monopsony power, which suggests that the bulk of monopsony is coming from "nonconcentration" sources, such as search frictions and job differentiation.

Webber (2015), using the LEHD finds little correlation between wages and employment concentration, but defines concentration as share of county X industry workforce employed at the firm. In contrast, more recent work, by Azar, Marinescu, and Steinbaum (2017), Benmelech et al. (2018), Rinz (2018), Lipsius (2018), Qiu and Sojourner (2019), and Hershbein et al. (2019) find negative and significant effect of concentration (measured as HHI at the CZ-Occupation level, or county X industry level, or county X “sector" level) on wages, although some of these papers only find effects in IV specifications. These differences suggest that more work on the definition of boundaries of the labor market is required, as well as credible identification of the effect of concentration.

$$
w_{i}\left(L_{i}, \sum L_{j}\right)=\alpha\left(L_{i}\right) w\left(\sum L_{j}\right)
$$


The $w\left(\sum j L j\right)$ term captures the aggregate inverse labor supply function. This is the way in which the wage of every worker changes depending on the amount of employment. If aggregate employment is low, then the wage is low. If the number of firms is small or a single firm has a large share of employment, then individual firms will be able to influence the wage they face by changing their employment. If $\alpha=1$ is constant, then this wage function is simply the Cournot model.

The addition to this simple Cournot model is the $\alpha$ scaling, which only depends on firm i's choice of employment. This term captures all the "competitive" labor supply frictions that would influence firm i's choice of employment even if "concentration" did not matter, for example search and differentiation. $\alpha$ scales the inverse aggregate labor supply curve by a factor that depends only on the employment choice of firm $i$, ignoring all the labor decisions of the other firms. Suppose the elasticity $\eta^{\text {comp }}=\frac{\alpha}{\alpha \prime\left(L_{i}\right) L_{i}}$ is constant. If $\eta^{\text {comp }}$ were large, then it would suggest that concentration was the primary source of monopsony. Writing the expression for the markdown we get:

$$
\frac{1}{\eta^{i}}=\frac{p_{i}-w_{i}}{w_{i}}=\frac{1}{\eta^{\operatorname{comp}}}+\frac{s_{i}}{\eta^{a g g}}
$$

With $s_{i}=l_{i} / L$ denoting the share of employment at firm $i$. We can solve this for the “competitive" LS elasticity to get $\eta^{\text {comp }}=\frac{1}{\frac{1}{\eta^{i}}-\frac{s_{i}}{\eta^{\text {agg }}}}$.

Webber (2015) finds the average firm employs $9 \%($ s.d. $=16)$ of the industry in its county, and estimates firm-specific labor supply elasticities of 1.08 on average. This combined 
with formula (1) above gives a competitive labor supply (LS) elasticity of roughly 1.1 (at $\eta^{\text {agg }}=$ 2.8 ). We can then plot the implied residual supply elasticity as the average firm employment share (or equivalent equal-firm HHI) changes. Figure 3 implies the bulk of the source of monopsony power is coming from competitive sources, and it implies that changing concentration would have a small effect on the LS elasticity. Note that the firm LS elasticity falls slowly as concentration increases, with falling from close to 1.1 to around 0.81 as concentration goes from 0 to 1 . This suggests there is still a considerable markdown (wages almost $50 \%$ of marginal product) even if concentration is extremely low.

We can also use comparable results from Bassier et al. (2021) in this volume, who argue the estimates recovered from the method used by Webber are too low, and emphasize using firmlevel variation in wages rather than worker-level. Bassier et al. find a residual supply elasticity of 4.5 , with an average firm share of $8.2 \%($ s.d. $=19)$. Figure 3 shows that even as firm shares approach 0 , the residual supply stays below 5 .

With heterogeneous firm employment shares, we can look at the share weighted markdown, given by:

$$
\left(\frac{p_{i}-w_{i}}{w_{i}}\right) s_{i}=\left(\frac{1}{\eta^{\operatorname{comp}}}+\frac{s_{i}}{\eta^{a g g}}\right) s_{i}
$$

And summing across firms yields:

$$
\sum\left(\frac{p_{i}-w_{i}}{w_{i}}\right) s_{i}=\left(\frac{1}{\eta^{\operatorname{comp}}}+\frac{H}{\eta^{a g g}}\right)
$$


In a Cournot-type model, the firm-specific $\eta=\frac{H}{\eta^{a g g}}$, the residual elasticity $\eta^{\text {comp }}$ is infinite and only concentration and the aggregate labor supply elasticity matters in determining markdown. Using the upper aggregate elasticity implied by Bartik (2018) the levels of HHI required to get a firm-level labor supply elasticity of less than 4 are all greater than 0.7 , well outside the range of existing estimates. The mean level of $\mathrm{HHI}$ at the 3-digit manufacturing industry X commuting zone level in Benmelech et al. 2018 is 0.23. Azar et al. (2018) find a 6-digit occupation X commuting zone HHI of .32. Hershbein et al. (2019) find commuting zone HHIs between .2 and .1 for non-manufacturing and around 0.35 in manufacturing. Rinz (2018) finds local HHI (at the industry X commuting zone level) has declined from 0.2 in 1976 to around 0.15 . The divergence of labor market definitions across papers means that we do not yet have a clear picture of whether the Cournot-plus-concentration markdown can account for the low elasticity of the firmspecific labor supply curve. But these levels of concentration would imply residual supply elasticities 3 to 6 times aggregate supply elasticities, and with the aggregate supply elasticities 1.5 or higher, would be generally larger than recent estimates.

The takeaway from these exercises is that concentration alone might have a difficult time accounting for the low labor supply elasticities estimated in the literature. Depending on the market definition used, concentration is too low, and the aggregate labor supply elasticities to local labor markets are too high for it to quantitatively matter: there is simply too much "competitive" market power.

One caveat is that we have chosen relatively large labor supply elasticity to the local labor market based on Bartik (2018). If we had instead gone with a smaller elasticity (.1 or .5) 
consistent with supply to any market (e.g., Chetty 2012) we could have rationalized firm-level labor-supply elasticities less than 3 with existing concentration estimates: a 0.2 to 0.4 Herfindahl and a .5 to 1.5 aggregate supply elasticity can rationalize firm-specific labor supply elasticities within the plausible 1-4 range (Sokolova and Sorensen 2018). We show this in Figure 3 for completeness, but remind readers that the measures of concentration used in the literature are generally computed at levels much finer than the aggregate labor market, and so the relevant supply elasticity is unlikely to be the aggregate one. While concentration may be important as a source of monopsony in some labor markets (e.g. extremely concentrated labor markets), nonconcentration (i.e. frictional) sources of monopsony also seem to be important.

We can compare the results of this exercise to the estimated parameters in Berger et al. (2020), who specify a full nested labor supply system. They obtain an inverse residual labor supply function of the form

$$
\log w_{i}\left(L_{i j}, L_{k j}\right)=\frac{1}{\eta} \log \left(L_{i j}\right)+\left(\frac{1}{\theta}-\frac{1}{\eta}\right) \log \left(L_{j}^{S}\right)+\left(\varphi-\frac{1}{\theta}\right) \log (L)
$$

Where $\mathrm{j}$ subscripts distinct markets, $L^{S}$ summarizes strategic interactions across firms, and $\mathrm{L}$ is an index of aggregate employment. ${ }^{\text {viii }}$ Using heterogeneous responses to corporate tax changes and the equilibrium in their model, they estimate $\eta=5.38$ and $\theta=.66$ and set $\varphi=0.5$. Thus, even if all strategic interactions were eliminated, so that $\frac{\operatorname{dlog} w_{i}\left(L_{i j}, L_{k j}\right)}{\operatorname{dlog} L_{i j}}=\frac{1}{\eta}$ the degree of labor market power would stay substantial, with markdowns of approximately 15-20 percent. 
Finally, we can do a similar exercise with Amazon Mechanical Turk. Using the data from Dube et al. (2020) we calculate the Herfindahl of MTurk jobs posted in a given hour X task category, which averages at 0.8 (consistent with other results showing high concentration on MTurk from Gray et al. 2013). But Dube et al. (2018) estimate a firm-specific labor supply elasticity of 0.14 . For concentration to be the primary source of monopsony, the aggregate labor supply elasticity must be quite small, roughly 0.112 . If we think of the aggregate labor supply elasticity on MTurk as akin to a Frisch hours labor supply elasticity, this is an order of magnitude below normal estimates of this parameter (e.g. Angrist et al. (2017) estimate an elasticity of 1.2 using experimental Uber data and Fehr and Goette (2007) estimate between 1.12 and 1.25 on Swiss bicycle messengers).

\section{An Inventory of Law and Policy Tools for Labor Market Monopsony.}

In this section, we address various types of labor market regulations and other laws that could (or do) address the problem of wage suppression caused by labor market monopsony. Solutions can either increase residual supply elasticities (competition), much as antitrust aims to do, or keep market power constant but impose either internal governance mechanisms or wage/benefit standards that prevent firms from exercising it. Finally, policies can allow firms to exercise monopsony power but ameliorate the resulting inefficiencies with e.g. employment subsidies. Table 1 gives a quick summary of the policies considered and how they address monopsony. In each case, we show how the regulation in question may address the various problems we identify; the limits of the regulation; and the costs that the regulation may impose 
on the economy. Our general theme is that these regulatory approaches seem to be lacking, just like antitrust law. Indeed, some may in fact exacerbate rather that ameliorate the monopsony distortion.

a. Wage Regulation

A much-discussed response to the problem of wage suppression is the minimum wage or living wage law. A minimum wage prohibits the employer from paying workers a wage below a certain level. Mandatory minimums in this spirit can be, and often are, applied to other aspects of work. For example, maximum hours laws limit the number of hours that workers can be required to work, or require extra pay for hours above that limit. Laws that require employers to meet minimum health and safety standards have a similar effect. They prevent an employer from underproviding what is effectively in-kind compensation in the form of relatively safe or pleasant working conditions.

The standard criticism of minimum wage laws is that they will result in unemployment as employers fire workers to whom they must pay a wage greater than then the workers' marginal revenue product. But this criticism assumes that labor markets are competitive. The more serious problem with minimum wage laws is that they can only help a small class of relatively poor people - workers who would otherwise be paid slightly less than the minimum wage, and not more deeply impoverished people, or workers higher on the wage scale. When the monopsonistic wage level exceeds the minimum wage, minimum wage laws have no effect. If the wage is only a small part of the total compensation, or total compensation is fungible between wage and non- 
wage components, minimum wages alone will have a negligible effect. Moreover, the minimum wage must be carefully calibrated: if the wage level is set too high, then disemployment effects may be greater than the wage benefits. It may be difficult for governments to calibrate the minimum wage correctly. On the whole, uniform minimum wage laws can be only a small part of the response to wage suppression caused by monopsonistic competition.

A more thorough and flexible wage-mandate response to pervasive monopsony would be wage boards, for example as is prevalent in Australia and in some US states for some industries (e.g. New York and California). While firm-specific minimum wages are theoretically ideal, a more practical proposal might involve setting industry and region-specific minimum wages. Wage boards periodically set wage floors by industry, occupation, and location, using nonpartisan expert appointees (in the Australian case) or tripartite employer-worker-government commissions (as in the US case) (Madland 2018). Dube (2019) calibrates effects of a system of wage boards on U.S. wage inequality.

b. Tax and transfer policies

It is well understood that the fiscal system solution to market power involves subsidizing the price paid by the firm. For example, the government could offer to pay a monopolist a subsidy for every unit sold, so that the monopolist voluntarily manufacturers and sells the number of units that it would produce in a competitive market. Transposed to labor markets, the firm would subsidize the wage. Standing alone, such a scheme would have unattractive distributive effects, but if a corporate tax on pure profits was coupled with a precisely tuned (i.e., 
equal to the optimal level of employment) subsidy on wages, the gains from alleviating the monopsony distortion via a subsidy could be redistributed.

Under this approach, the government should apply the subsidy only to employers with monopsony power, and the extent of the subsidy should be a function of the degree of monopsony power. But the existence, and especially degree, of labor market power is never selfevident. It is the domain of antitrust law in the first place to determine whether an employer has power in a labor market, and this fact-intensive inquiry seems to require lengthy hearings by courts. Further, firms will have an incentive to cherry-pick the best workers under the wage subsidy scheme. Taxes are not used to police product market power and are likely not a good instrument for labor market power.

A popular policy that has unanticipated consequences under monopsony is the Earned Income Tax Credit (EITC). The EITC subsidizes earnings of low-income households, and is among the largest forms of redistribution in the United States. However, in monopsonized labor markets, the EITC can have perverse consequences. By increasing the effective (after-tax) wage earned by the worker, it encourages people to enter the labor market (shifting the labor supply curve to the right), enabling employers to pay a lower wage to the incumbent workers. While the EITC can undo the disemployment effects of monopsony, it will also transfer a share of those benefits to employers while reducing wages for incumbent workers. ${ }^{\mathrm{ix}}$

But a subsidy that leverages private information could be implemented in labor markets where firms do not have discretion over hiring. Imagine the following employment regime. 
Employers are required to make a public list of all the jobs that they offer, along with the qualifications and compensation, and are further required to hire the first qualified person who applies for it. Then monopsony power can be eliminated by subsidizing wages paid by employers. This subsidy has a similar economic motivation as the common-ownership selfassessed tax proposed by Posner and Weyl (2018); a monopsonist employer has an incentive to quote too low a wage, and the subsidy blunts this incentive. The "take-all-comers" hiring policy is essential to make this work, but may not be such a stretch in the era of gig-work where companies like Uber operate by offering a highly standardized form of work to workers who are hired based on their conformity to a rigid set of ex-ante specified qualifications.

A recent literature on "robust monopoly regulation" (Guo and Shmaya 2019) may also be useful for adjudicating between wage mandates and subsidies. The idea in robust policy design is that policymakers do not even know the distributions of possible worker tastes, outside options, nor firm valuations of workers. Can optimal (in some sense) policies be even formulated? The robust mechanism design literature suggests that not only can such policies be characterized, they are often simpler and much more transparent than policies that presuppose policymaker knowledge. Translating their product market results into the labor marketcase, Guo and Shmaya find that the "regret-minimizing" policy features either a minimum wage or a (capped) wagesubsidy (or both), depending on how much the profits of business are valued relative to workers' wages.

Worth considering as part of the policy mix for combating monopsony is unemployment insurance (UI). While a large literature considers the optimal level of unemployment insurance in 
light of the insurance-incentives trade-off, little of this literature has accounted for the role of unemployment insurance in blunting employer market power. For example, legitimate reasons to quit (e.g. harassment on the job or health and safety standards) can allow a worker to exit employment into the UI system, putting some brakes on employer ability to exert monopsony power. However, almost all UI systems do not permit otherwise voluntary quits to take UI, and so the role of UI in increasing the outside option of workers is limited, and may account for why recent evidence has shown that within-firm increases in UI generosity do not lead to appreciably higher wages (Jager et al. 2019). The enormous expansion of the UI system during the COVID pandemic may alter the terms under which workers are eligible for UI, increasing its role as a possible counterweight to monopsony. ${ }^{\mathrm{x}}$

c. Mandatory benefits

Workers are protected by a range of laws that require employers to offer certain benefits to them. Federal mandates include workers compensation, safety and health requirements, family and medical leave requirements, and special treatments for veterans. ${ }^{\mathrm{xi}}$ States also impose mandates. Illinois, for example, requires employers to give workers time for a meal if they continuously work 7.5 hours or more, and prohibits employers from penalizing employees who miss work in order to vote or serve on a jury. ${ }^{\text {xii }}$ Mandates can be loosely defined as legally required in-kind transfers from the employer to the workers where the workers attach or may attach an intrinsic value to the benefit. We abstract away from certain legal requirements that are designed to increase workers' bargaining power, for example, union organization rights. 
These policies have often puzzled economists because they seem to substitute the government's judgment about the conditions of employment for the employee's own judgment as to what may be best for her. Consider, for example, a mandate that employers grant unpaid leave to workers who experience a family medical emergency. It would seem that if workers value unpaid leave of this type a sufficient amount, employers would grant it to them even in the absence of the mandate. The unpaid leave is simply an in-kind benefit - effectively, a kind of weak employer-supplied insurance policy. Suppose, for example, that a worker would be willing to pay $\$ 100$ for such a policy because it gives her peace of mind, while the cost to the employer is only, say, $\$ 50$ in lost productivity. By incorporating unpaid leave into the employment contract, the employer should be able to reduce the wage by between $\$ 50$ and $\$ 100$. Summers (1989) observes that mandates might be justified where externalities are present, or for paternalistic reasons, but otherwise they are a puzzle.

The logic is the same if the employer is a labor monopsonist. Indeed, it is possible that the labor monopsonist has stronger incentives than a non-monopsonist to offer certain packages of benefits because the monoposonist will obtain a larger share of the marginal surplus from retained workers. To see why imagine (following Spence's (1975) model of monopoly) that the marginal worker (the one indifferent between working at this firm and the outside option) values amenities more than all the other inframarginal workers A monopsonist may have an incentive to offer a package of low wages and amenities that appeals to the marginal worker but is also transferring surplus from the inframarginal workers to the employer. ${ }^{\text {xii }}$ In such circumstances, 
labor market mandates, just as quality standards in product markets, may have a role to play in curbing the distortion in job design induced by monopsony ${ }^{\mathrm{xiv}}$.]

As Summers also notes (1989, p. 179 n.2), the story is more complex if, as will usually be the case, the monopsonist has limited information about employees and potential hires. Employers may use packages of wages and benefits to avoid adverse selection problems but that are, from the social standpoint, inefficient. But a policy of mandating benefits in such circumstances does not have straightforward efficiency effects.

Further, to the extent that the cost of benefits is larger than the value workers have for those benefits, mandates will act as a tax, and thus magnify the monopsony distortion, resulting in even lower employment and wages than the competitive case. We suspect that mandates will not generally help address labor monopsony power except in the limited case where the minimum wage is binding, and so the addition of a mandate has the effect of increasing the effective compensation of a low-income worker. Even here, however, raising the minimum wage would be the better remedy to the problem of labor monopsony, unless the wage is a small share of total compensation. Mandates do not address wage suppression caused by monopsony power.

\section{d. Job Protection}

In the United States, most jobs are at-will, meaning that the employer can fire the worker for any reason not specifically forbidden by law (such as racial discrimination). In one state, Minnesota, the law provides that employers may fire workers only "for cause." Under the for- 
cause standard, employers may fire workers only if they can prove that the workers are unable or unwilling to perform the job up to standards. In other countries, some workers have even more secure forms of tenure. Laws that put limits on termination of workers also typically prevent the employer from taking lesser forms of actions against workers like reducing wages, or even failing to make cost-of-living adjustments.

A crucial observation of monopsonists is that they are labor constrained: they always want more labor at the given wage, and so it is unclear why monopsonists would fire workers without cause (other models, like efficiency wages, may be needed to rationalize these protections).

In the simplest variant of the Burdett-Mortensen model of search, however, job protections could be understood as lowering the (exogenous) separations rate, and thus the tightness of the labor market (ratio of recruitment to separations rate) increases, moving the labor market closer to efficiency. Because fewer workers are fired, fewer are available to hire, and employers must compete more vigorously to hire those who remain. But if employers lose profits because they cannot fire underperforming workers, and choose vacancies and recruitment effort, then the employer reduction in recruitment effort may outweigh the reduction in the separation rate.

Job protection rules may reduce the bargaining power of employers by depriving them of the ability to fire a worker who refuses to accept a low wage or insists on a higher wage. But they do not help workers in concentrated labor markets: the initial wage will be set at the 
monopsony rate. At most, they help workers who obtain work at the market wage, or a relatively high wage, and then lose bargaining power as the labor market consolidates or the workers' outside options diminish for other reasons. These workers will be unable to obtain raises that they would receive in a competitive labor market.

Job protection also has negative consequences. Many economists worry that the job tenure laws in some countries damage the macroeconomy by decreasing labor mobility, and reducing employers' incentives to hire in the first place. Labor rigidity may also make it more difficult for economies to recover from recessions.

A weaker form of job protection comes in the form of notice requirements. The Worker Adjustment and Retraining Notification Act requires employers to give workers notice before laying them off. Notice benefits workers by enabling them to start their job searches while they are still being paid. Notice requirements may therefore enhance workers' bargaining power by reducing search costs, although perhaps only modestly.

e. Occupational licensing

Many types of employment are subject to occupational licensing statutes. These statutes require people to undergo training and certification before offering services to the public. Traditional examples include lawyers and doctors, but in the last few decades the list of occupations that are subject to these rules has lengthened considerably, and now includes (depending on the state) hair dressers, auto mechanics, financial advisers, civil engineers, 
electricians, and funeral directors, among many others. A survey reported in Kleiner and Krueger 2009) found that $35 \%$ of workers were licensed or certified.

The traditional justification for occupational licensing is quality control. If the government can screen out incompetent service providers, consumers will benefit. Many economists are skeptical of this justification and have argued that the main effect of occupational licensing has been to erect entry barriers that raised prices for services, reduced supply, and benefited incumbents. The crucial observation here is that occupational licensing lowers the supply of labor to a given market, and thus raises wages of the licensed, lowers profits of firms (and raises prices to consumers), and lowers the wages of the unlicensed.

Unfortunately, occupational licensing also imposes a cost on people who want to enter the workforce in the first place - since they must pay for training that may otherwise be unnecessary, as well as the fees for certifications. For this reason, occupational licensing may not on balance be a useful way to counter employer monopsony power.

It is possible that occupational licensing could help workers counter labor monopsony power of employers, if licensing makes the supply to the firm more elastic as well as lower, which may or may not be the case, and has not been a consideration in the empirical literature on licensing. Monopsony also implies that the deadweight loss from binding occupational licensing will be smaller than if the no-licensing equilibrium were competitive, so the social costs of licensing are smaller. 
f. Government subsidies, including training and employment

Numerous government programs offer various skills training for people. The U.S. government subsidizes student loans and offers tuition grants. States and local governments provide subsidized schooling, vocational training, and university training. Many programs help workers who have lost jobs. For example, the Department of Labor runs the Employment and Training Administration, which offers retraining programs to dislocated workers, among others. The Workforce and Innovation Opportunity Act, passed in 2014, provided additional resources for supporting and retraining people who have lost their jobs. ${ }^{\mathrm{xv}}$ States and local governments also offer numerous services to unemployed workers, including training and matching. ${ }^{\text {xvi }}$

These programs offer benefits to ordinary people but most of them do not address the problem of labor market power. Consider, for example, federal grants and loan subsidies for students who seek to attend college. In the absence of such benefits, people will either borrow in the private market or refrain from going to college. In the first case, the benefit is equal to the difference between the cost of borrowing in the private market and cost of subsidized borrowing along with any grants. In the second case, the benefit is equal to the difference between future income that is obtained as a result of the college education (net of costs) and future income otherwise obtained. In both cases, the benefit is a transfer from taxpayers to the generally lowerincome people who qualify for these programs. Employers may be benefited from the larger pool of qualified labor. Monopsonistic employers remain free to use their market power to suppress the wages of the people they hire. It is even possible that as the pool of trained workers increases, the workers lose bargaining power, which further enhances the bargaining power of 
monopsonistic employers, who thus obtain a larger share of the surplus generated by the government programs.

Insofar as worker and firm underinvestment in training is a symptom of excessive labor market power, policies to encourage training can mitigate the distortion. But without reducing the degree of monopsony power the bulk of the returns from training will likely be captured by employers. Indeed, some of the hunger for government training programs emanating from the private sector may be due to labor market power: monopsonists are always labor constrained, and demand more and more skilled labor without wanting to raise the wage.

Some educational programs may, however, help counter labor market power. We have in mind job-retraining programs, particularly those that give relatively general skills that facilitate occupational mobility. To see why, imagine that a single meat-processing plant dominates the local labor market for meat-processing workers. Because the workers have few outside options if they are fired, the employer can suppress wages. Now imagine that the government offers job retraining for anyone who has been fired from a job. The program improves the value of the workers' outside option by enabling them to earn a higher income once they undergo the program after they have been fired. This should increase their bargaining power vis-à-vis the employer, who in turn should refrain from suppressing wages as much as it otherwise would. Note that this pathway for countering labor market power works by reducing search frictions for workers rather than by reducing market concentration or directly regulating the terms of employment. A recent paper by Manoli and Patel (2019) compares experimental results on job 
search assistance in Nevada with Job Corps and Workforce Investment Act Training programs, and finds that only the former delivers persistence earnings gains.

Retraining programs, and other programs that help laid-off workers find new, wellpaying jobs, could thus be a useful way to counter labor market power. But these programs also have many limitations. They are costly and will only be justified when the benefits for workers exceed those costs. It may also be difficult for the government to offer appropriate retraining programs. The government needs to be able to forecast the demand for the jobs for which training is needed, and the willingness of workers to take those jobs and undergo training for them. This type of forecast may be challenging.

\section{g. Job Standardization}

None of the proposals we have discussed address the problem of job differentiationwhere labor market power arises because apparently similar jobs are actually quite different for workers because of variation in amenities across workplaces. The simplest amenity to think about is commute time: employers that are dispersed across residential locations have more market power than employers that all occupy a dense central business district. But jobs being far away from each other could be true in a much higher-dimensional space of job characteristics than simply distance. This problem seems intractable because the variation of amenities may reflect the different preferences of workers, and employers would normally be justified in catering to different preferences. But the result is that employers can underpay workers who cannot find valued amenities in other workplaces. 
At least as a theoretical matter, however, workers (and the economy) could benefit if labor market differentiation was deterred at the margin. ${ }^{\text {xvii }}$ Unions have sometimes performed this function by standardizing jobs across firms within industries (Freeman and Medoff 1984). Non-wage characteristics of unionized jobs are very important to workers' preferences for unionization (Farber and Saks 1980). The law also plays a role in standardizing work. Minimum wage and maximum hours laws push employers to offer standard eight-hour workdays. This puts a limit on the duration of shifts, which in turn should reduce the variation across employers of this dimension of work. Government-mandated health and safety regulations should also reduce job differentiation by putting a floor under the health and safety conditions of any workplace. However, as far as we know, no study documents the job-differentiation effects of union practices and legal regulations on employer market power, likely because many of these regulations also come along with mandated changes in wages, limiting the value of the exercise.

Some markets for services seem to be naturally standardized. Consider, for example, the services offered to households by plumbers, electricians, drycleaners, locksmiths, carpenters, and other skilled workers. Because these workers typically sell services to numerous households, they are not subject to typical labor monopsony pressures. The law recognizes this distinction by classifying such workers as independent contractors and denying them the protections of employment labor law—including, for example, minimum wage laws, and the right to unionize. The law apparently assumes that market competition protects these workers, and so legal protections are unnecessary or less necessary. In contract, if a (say) plumber goes to work for a single firm like the owner of an office building or hotel, the plumber is likely to be classified as 
employee because the buyer of her services has more "control" (or labor market power) over her (Posner 2020b).

However, in recent years some employers have evaded the work restrictions imposed by employment regulations by classifying employees as independent contractors. Consider, for example, the rise of ride-sharing companies, which compete with taxi and limo companies. When taxi and limo companies organize as employers, their drivers are treated similarly, and this means that a driver will not see much difference between working for employer A and for employer B. In contrast, an independent contractor could be given insurance by company A and not by company B. This means that the independent contractor, while legally treated as independent of the ride-sharing companies, may actually be more constrained in his or her ability to move from one to another.

Thus, companies might be able to gain market power over workers if the independent contractor rules are not enforced with sufficient strictness, but at the same time relaxation of the independent contractor rules might also give workers flexibility that they value. How these factors balance out is a complex empirical question. Nonetheless, recent efforts to restrict abuse of the independent contract rule, in California and elsewhere, seem appropriate.

h. Support for unions

Workers have historically turned to union organization to counter the labor market power of employers. Unionization deprives the employer of its main source of market power: the ability 
to set the wage. If the employer does so, the union strikes, and the threat of the strike should deter wage suppression in the first place. However, unions are fragile organizations. They must maintain discipline among members, and employers can bust unions by countering those disciplinary efforts.

Governments can counter wage suppression by providing legal protections for and subsidies to unions. This strategy has been pursued in many countries. In the United States, the law prohibits employers from engaging in various types of union-busting activities, including bribery of workers, intimidation, the creation of company unions, and much else. The law also regulates union elections, collective bargaining, and work stoppages. These regulations limit fraud and coercion; enhance transparency; and encourage peaceful negotiation and collective actions.

Unions operating in monopsonistic labor markets also generate spillovers to other, nonunion, workers, without any threat effects. This is because union density raises wages for unionized employers, and non-union employers must raise their wages to compete for workers.

Collective bargaining by unions may allow contracting to overcome a lack of competition. In an extreme example, where the marginal product of labor is constant, transferring monopoly power to workers can be efficient: rather than wages being distorted downwards by monopsony, resulting in too few workers, the union will set the wage equal to marginal product (having no reason to set it higher than that; as then the firm exits). In a more realistic case with diminishing marginal product of labor, the choice between laissez-faire monopsony and union 
monopoly will depend on the elasticity of labor demand versus labor supply. Crucially, however, whether or not efficiency is enhanced by firm-level unions depends on whether employment increases under the union. Existing evidence is mixed: Frandsen (2013) suggests employment increases for low skill workers and decreases for high-skill workers.

When the source of monopsony is job differentiation, either due to specific skills or idiosyncratic tastes, unions may have a further role in reducing monopsony power by facilitating contracting, overcoming asymmetric information and commitment failures. A union may use non-pecuniary rewards to facilitate first-degree price discrimination, and then use the wage to split the resulting (first-best) surplus.

Despite the legal protections they have been given, unions have lost ground in the United States over the last fifty years. There are many reasons, including technological change and globalization. Employers have developed more sophisticated union-busting strategies (Schmitt and Zipperer 2009); workers have become increasingly isolated from each other as a result of broad economic trends, and this isolation interferes with organization; and right to work laws at the state level have further weakened union discipline by allowing workers to free-ride on the collective bargaining efforts of the union leadership. Many employers have taken advantage of legal forms that allow them to classify workers as independent contractors (as discussed above) or fragment their workforce by operating through independent franchisees. General economic changes have also apparently created more highly differentiated jobs, which further interferes with organization as well as supplying employers with an independent source of market power. 
i. Shareholder Activism/Codetermination

Monopsony implies that a component of firm profit is rents from underpriced labor. This profit then accrues to shareholders. But what if at least some of these shareholders are workers themselves?

Suppose workers have a portion $\alpha$ of the firm's shares, and managers weight shareholders' interests according to shares held. The objective function of the firm then becomes:

$$
\alpha((p-w) l(w)+w l(w))+(1-\alpha)(p-w) l(w)=(p-w) l(w)+\alpha w l(w)
$$

Thus, the monopsony incentive to distort the wage downwards is mitigated to the extent that the firm's manager internalizes the wage bill. Of course, the equation above does not effectively capture the true objective of the (partially) labor-managed firm: if the labor supply is the extensive margin (number of workers) the question of how many workers a worker-owned firm would want needs to be answered, and that depends on how profits are shared and the extent of diminishing returns, as in the Ward (1958) model of the worker-owned firm under market socialism (see also Dow 2003).

A prominent example of employee-ownership is employee-stock ownership plans (ESOPs), which are the subject of an extensive economics literature, much of it using the NBER Shared Capitalism database. Roughly $20 \%$ of private sector American workers own some of the stock their company. Kruse (2016) surveys this literature and finds that employee ownership is 
linked to better company performance. Part of the mechanism (besides higher compensation, effort and less conflict) is lower turnover and absenteeism, which suggests that employee-owned firms are moving up the labor-supply curve facing the firm. However, cleanly identified causal effects of employee ownership are still missing from the literature.

Union pension funds have been used successfully to alter corporate governance practices, particularly around labor relations. By organizing shareholders around worker interests and mobilizing proxy votes, union pension funds are able to influence a variety of firm decisions. But most pension funds, wanting diversification of risk, would likely invest only a small share of their savings in the firms that employ their members. And workers' holdings may be small relative to holdings of other investors, so $\alpha$ is small. Even if $\alpha$ were large, firm managers might be required, by fiduciary duty, to exploit monopsony power even against some of their owners.

By asking its managers to raise wages in monopsony, the pension fund would a) lose some value in profits, but b) increase contributions and members. Depending on the degree of monopsony, exposure to the firm, and the extent of contributions of workers, the value to the pension fund of b) could offset the costs from a).

One interesting case is public sector union pension funds, for example institutions like CalPERS. If we take literally the idea that these funds should maximize the returns to their members, then it may be sometimes appropriate for these funds to demand that monopsonistic firms raise wages. Higher wages benefit the workers more than their lost capital gains. Tax revenues should also increase because the tax rate on wages is higher than the tax rate on capital 
gains - although the problem is complicated because the public goods funded by these tax gains will benefit people other than members, and the taxes paid on capital gains will mostly be paid by non-members as well. But to the extent that the tax bill increases, and to the extent that public sector union members get higher wages from additional tax revenue, public sector pension funds may have a pecuniary interest in requiring their holdings to raise wages.

Another way to induce a positive $\alpha$ is via worker codetermination, which would not require ownership of firm shares. Instead workers get votes on firm policies, including wagesetting policies. To the extent that workers' votes count this will influence firm wage-setting and mitigate the exercise of monopsony power.

\section{j. Macroeconomic considerations}

A considerable amount of theoretical and quantitative research has gone into the cyclical implications of job search models with bargaining, but comparatively much less has gone into variants of search models that feature monopsonistic wage setting.

The job search model implies that the residual labor elasticity will fall during economic downturns because workers have more trouble finding new jobs. Depew and Sorensen (2013) and Webber (2015) both find evidence for this hypothesis. Tight labor markets are also more competitive. Thus, countercyclical macroeconomic policy that successfully minimizes job loss during downturns will have broadly positive effects on labor market efficiency and wage levels. 
While more research is necessary, it is intriguing to consider monopsony as the proximate mechanism behind the famous "wage curve" widely used in macro, where wages and unemployment exhibit a negative relationship. Models like the Mortensen-Pissarides model or the Shapiro-Stiglitz model deliver wage curves because of how unemployment lowers the outside option of workers. A monopsonistic variant would suggest that a low residual elasticity (perhaps proxied by a low voluntary quit rate) is the mechanism that transmits high unemployment into low wages, not outside options.

Given the recent staggering increase in unemployment due to COVID-19, even as labor demand for essential workers has increased, the relationship between macroeconomic slack and labor market competition is potentially even more salient. Lack of labor market competition may be one reason compensating wage differentials for essential workers facing increased hazards have not materialized (Cajner et al. 2020).

k. Who enforces?

All of these proposals raise a cross-cutting question of agency costs. Many employment regulations are enforced by federal agencies, including the Occupational Safety and Health Administration and the Equal Opportunity Employment Commission. Others, like minimum wage laws, are enforced by state and local government as well as by the federal government. In all these cases, the government serves as an agent of the workers. Union leadership, too, serves as an agent for the members of the union. And in our pension example, one might think of the pension as serving as an agent for workers, though indirectly. Many employment laws are 
enforced by private litigation, and because of the high cost of litigation, usually in the form of class actions, where private lawyers serve as agents for classes of workers. Those class actions can be thought of as contingent unions that spring into existence to enforce the law. All of these approaches raise questions about whether the agent actually has the interest of the workers at heart.

Worries about agency costs have led in many cases to a round of meta-regulation. The law requires unions to act in the interest of workers, and the same is true for class action lawyers. But we might also wonder whether the government agents charged with enforcing the law will act in the interest of workers who often have little political power. The old union movement was based in part on suspicion about government responsiveness to the interests of workers, and such concerns continue to be aired today.

Pervasive monopsony, together with employment at will, also means that whistleblower mechanisms for enforcement (like OSHA) will be weaker in labor markets than in other markets. Under monopsony, inframarginal workers are getting rents from their job, and thus would be afraid of termination or forgone pay increases. Employer retaliation for whistleblowers is thus costly and difficult to prevent.

Conclusion

We write (our final revision) during a period of upheaval in labor markets in the late spring of 2020. The COVID-19 pandemic, and the government responses to it, shut down 
numerous businesses, causing a massive spike in unemployment. We will surely learn more about how labor markets operate as data are gathered and analyzed but it is not premature to make two observations.

First, because laws allowed "essential workers" to work while the general economic collapse eliminated (at least in the short term) alternative employment for these workers, the employers of essential workers gained immense monopsony power over them. Worse, essential workers who quit because they were unpaid or feared the risks of infection were generally not entitled to unemployment insurance. This may explain why employers (with the possible exception of unionized employers) by all reports did not offer adequate protective equipment to workers, and may not have increased wages commensurate with risk. ${ }^{\text {xviii }}$

Second, the facility with which many skilled workers were able to switch from commuting to offices to working at home may radically expand the geographic scope of labor markets. If it turns out to be the case that many employers are relatively indifferent between athome and in-office workers, then the labor market for many jobs is nationwide or even worldwide. These larger labor markets will also necessarily be more competitive. This will be good for the workers affected, but also may open up a new class division between workers who can work anywhere (probably, mainly higher-skill office workers) and those whose jobs require them to be in a certain place (mostly, lower-skill workers though with many exceptions like doctors), with the former receiving a much larger share of their product than the latter. 
Economic models encourage one to find the common features of apparently different things, but the differences between goods and human beings are pretty significant. Humans often like to disperse themselves across large areas, resulting in thin populations that are vulnerable to monopsony. Goods don't care where they are located and are happy to reside in warehouses until shipped across a national market. Humans spend a lot of time at work and develop complex preferences over workplace amenities, colleagues, location, and much else. Goods are remarkably standardized and (within classes) similar to each other, easy to compare and evaluate. Humans are unable to commit themselves to doing predefined tasks for a long period of time. Goods, when they aren't defective, perform and depreciate in a predictable fashion. If perhaps for most goods in national markets, the ideal of perfect competition is a reasonable approximation, the non-ideal of monopsonistic competition seems to be the norm for labor markets.

Not all goods are so well-behaved. Housing is notoriously complex, and bargaining failures are ubiquitous. Long-term service relationships, financial products, joint ventures, tech platforms, and other complex commercial activities also pose challenges to antitrust laws and other forms of legal regulation. But labor remains in a class by itself - not only because of its complexity but also for its importance to the well-being of the vast majority of people.

For this reason, the relatively hands-off approach of the law to consumer products is not appropriate for labor markets. In the hands-off approach, some modest disclosure and safety rules supplement an antitrust regime that treats abusive market practices as exceptional. For labor 
markets, even a far more robust antitrust presence would be far from adequate for squeezing out the inefficiencies of monopsony.

We have surveyed a range of other laws, real and imaginary, that may be helpful at the margin. Some of the laws we have looked at reduce the wage-setting power of firms- - by, for example, allowing poaching and promoting unionization. Others, like the minimum wage law, act as more direct constraints on the choices that employers can make. And a third group affect the incentives of employers by giving workers voting power or a share of the capital. But the problem of labor market monopsony is stubborn.

References

Acemoglu, Daron, and Jörn-Steffen Pischke. 1998. "Why Do Firms Train? Theory and Evidence." The Quarterly Journal of Economics 113(1):79-119.

Allen, David G. 2008. "Retaining Talent: A Guide to Analyzing and Managing Employee Turnover." SHMR Foundations. https://pdfs.semanticscholar.org/9c32/f1c8afb5ca3aa4020ca427 $\underline{71 c 55 c c a e e 2 \text { eed.pdf }}$

Anderson, Simon P., André De Palma, and Jacques-François Thisse. 1992. Discrete Choice Theory of Product Differentiation. Cambridge, MA: The MIT Press. 
Angrist, Joshua D., Sydnee Caldwell, and Jonathan V. Hall. 2017. “Uber vs. Taxi: A Driver's Eye View.” NBER Working Paper 23891.

Arnold, Daniel. 2020. "Mergers and Acquisitions, Local Labor Market Concentration, and Worker Outcomes.” Working Paper. https://scholar.princeton.edu/sites/default/files/dharnold/file s/jmp.pdf

Arnott, Richard. 1989. "Housing Vacancies, Thin Market, and Idiosyncratic Tastes.” The Journal of Real Estate Finance and Economics (2)(1): 5-30.

\begin{abstract}
Arnott, Richard, and Mashahiro Igarashi. 2000. "Rent Control, Mismatch Costs and Search Efficiency." Regional Science and Urban Economics 30(3):249-288.
\end{abstract}

Ashenfelter, Orley, and Alan B. Krueger. 2018. “Theory and Evidence on Employer Collusion in the Franchise Sector.” NBER Working Paper No. 24831.

Azar, José, Steven Berry, Ioana Marinescu. 2019. “Estimating Labor Market Power.” Available at SSRN 3456277. https://papers.ssrn.com/sol3/papers.cfm?abstract_id=3456277.

Azar, José, Ioana Marinescu, and Marshall I. Steinbaum. 2020. "Labor Market Concentration.” Journal of Human Resources, Forthcoming. 
Azevedo, Eduardo. 2014. "Imperfect competition in two-sided matching markets." Games and Economic Behavior, 83, 207-223.

Bartik, Alexander W. 2018. "Moving Costs and Worker Adjustment to Changes in Labor Demand: Evidence from Longitudinal Census Data.”

Bassier, Ihsaan, Arindrajit Dube, and Suresh Naidu. 2019. "Monopsony in Movers: The Elasticity of Labor Supply to Firm Wage Policies.” Working Paper.

Benmelech, Efraim, Nittai Bergman, and Hyunseob Kim. 2018. "Strong Employers and Weak Employees: How Does Employer Concentration Affect Wages?” NBER Working Paper No. 24307.

Berger, David W., Kyle Herkenhoff, and Simon Mongey. 2018. “Labor Market Power.” NBER Working Paper No. 25719.

Bertrand, Joseph. 1883. "Review of Cournot's 'Rechercher sur la Théorie Mathématique de la Richesse'." Journal des Savants 499:508.

Bowles, Samuel, and Herbert Gintis. 1976. Schooling in Capitalist America: Educational Reform of Economic Life. Routledge \& Kegan Paul. 
Breza, Emily, Supreet Kaur, and Nandita Krishnaswamy. 2019. "Scabs: The Social Suppression of Labor Supply.” NBER Working Paper No. 25880.

Broda, Christian, and David E. Weinstein. "Globalization and the Gains from Variety." The Quarterly journal of economics 121.2 (2006): 541-585.

Burawoy, Michael. 1979. Manufacturing Consent: Changes in the Labor Process under Monopoly Capitalism. Chicago, IL: The University of Chicago Press.

Burdett, Kenneth and Dale Mortensen. 1998. "Wage Differentials, Employer Size and Unemployment." International Economic Review, 39(2): 257-273.

Cajner, Tomaz, Leland Dod Crane, Ryan Decker, John Grigsby, Adrian Hamins-Puertolas, Erik Hurst, Christopher Johann Kruz, and Ahu Yildirmaz. 2020. “The U.S. Labor Market During the Beginning of the Pandemic Recession." Available at SSRN 3595452. https://papers.ssrn.com/sol3 /papers.cfm?abstract $\mathrm{id}=3595452$.

Caldwell, Sydnee and Emily Oehlsen. 2018. "Monopsony and the Gender Wage Gap: Experimental Evidence from the Gig Economy." Massachussetts Institute of Technology Working Paper. https://sydneec.github.io/Website/Caldwell_Oehlsen.pdf. 
Caldwell, Sydnee, and Oren Danieli. 2018. "Outside Options in the Labor Market.” Unpublished Manuscript. https://scholar.harvard.edu/files/danieli/files/danieli_jmp.pdf.

Caldwell, Sydnee, and Nikolaj Harmon. 2019. "Outside Options, Bargaining, and Wages: Evidence from Coworker Networks." Unpublished Manuscript. https://sydneec.github.io/Websit e/Caldwell_Harmon.pdf

Card, David, Ana Rute Cardoso, Joerg Heining, and Patrick Kline. 2018. "Firms and Labor Market Inequality: Evidence and Some Theory." Journal of Labor Economics 36(S1):S13-S70.

Card, David, Jochen Kluve, and Andrea Weber. 2018. "What Works? A Meta-Analysis of Recent Active Labor Market Program Evaluations." Journal of the European Economic Association 16(3):894-931.

.2010. "Active Labour Market Policy Evaluations: A Meta-Analysis." The Economic Joumal 120(548):F452 F477.

Chetty, Raj. 2012. "Bounds on Elasticities with Optimization Frictions: A Synthesis of Micro and Macro Evidence on Labor Supply." Econometrica 80(3):969-1018.

Cho, David. 2019. "Essays on the Determination of Employment and Wages." PhD Dissertation. Princeton University. https://dataspace.princeton.edu/jspui/bitstream/88435/dsp01xs55mf94k/1/ Cho princeton 0181D 13042.pdf 
Coase, Ronald H. 1972. "Durability and Monopoly." The Journal of Law and Economics 15(1):143-149.

Department of Justice. 2010. “Justice Department Requires Six High Tech Companies to Stop Entering into Anticompetitive Employee Solicitation Agreements.” Available at: https://www.justice.gov/opa/pr/justice-department-requires-six-high-tech-companies-stopentering-anticompetitive-employee.

Depew, Briggs, and Todd Sorensen. 2013. "The Elasticity of Labor Supply to the Firm Over the Business Cycle.” Labour Economics 24:196-204.

Diamond, Peter. 1971. “A Model of Price Adjustment.” Journal of Economic Theory 3(2):156168.

Dixit, Avinash K., and Joseph E. Stiglitz. 1977. "Monopolistic Competition and Optimum Product Diversity.” The American Economic Review, 67(3): 297-308.

Dow, Gregory K. 2003. Governing the Firm: Workers' Control in Theory and Practice. Cambridge, UK: Cambridge University Press.

Dube, Arindrajit, Laura Giuliano, and Jonathan Leonard. 2019. "Fairness and Frictions: The Impact of Unequal Raises on Quit Behavior.” American Economic Review 109(2):620-663. 
Dube, Arindrajit, Jeff Jacobs, Suresh Naidu, and Siddharth Suri. 2020. "Monopsony in Online Labor Markets." American Economic Review: Insights 2:33-46.

Dube, Arindrajit, Alan Manning, and Suresh Naidu. 2018. "Monopsony and Employer Misoptimization Explain Why Wages Bunch at Round Numbers.” NBER Working Paper No. 24991.

Fantasia, Rick. 1995. "From Class Consciousness to Culture, Action, and Social Organization." Annual Review of Sociology 21:269-287

Farber, Henry, and Daniel Saks. 1980. "Why Workers Want Unions: The Role of Relative Wages and Job Characteristics.” Journal of Political Economy 88(2):349-369.

Fehr, Ernst, and Armin Falk. 1999. "Wage Rigidity in a Competitive Incomplete Contract Market." Journal of Political Economy 107(1):106-134.

Fehr, Ernst and Lorenz Goette. 2007. "Do Workers Work More if Wages Are High? Evidence from a Randomized Field Experiment." The American Economic Review 97(1):298-317. 
Flinn, Christopher, and Joseph Mullins. 2019. "Firms' Choices of Wage-Setting Protocols in the

Presence of Minimum Wages" Available at:

http://www.nyu.edu/econ/user/flinnc/papers/FirmChoices FM.pdf

Freeman, Richard B., and James L. Medoff. 1984. What Do Unions Do? New York, NY: Basic Books.

Frandsen, Brigham. 2013. "The surprising impacts of unionization on establishments:

Accounting for selection in close union representation elections." Unpublished Manuscript. Department of Economics, Brigham Young University.

Gabaix, Xavier, David Laibson, Deyuan Li, Hongyi Li, Sidney Resnick, and Casper G. de Vries. 2016. "The impact of competition on prices with numerous firms." Journal of Economic Theory $165: 1-24$.

Goolsbee, Austan, and Chad Syverson. 2019. "Monopsony Power in Higher Education: A Tale of Two Tracks.” NBER Working Paper No. 26070.

Granovetter, Mark S. 1974. Getting a Job: A Study of Contacts and Careers. Cambridge, MA: Harvard University Press. 
Gray, Mary-Louise, Sara Kingsley, and Siddharth Suri. 2018. "Monopsony and the Crowd:

Labor for Lemons?" Available at SSRN 3257857 https://papers.ssrn.com/sol3/papers.cfm?abstrac

$\underline{\mathrm{t} i \mathrm{id}=3257857}$

Guo, Yingni, and Eran Shmaya. 2019. “Robust Monopoly Regulation.” ArXiv, abs/1910.04260. https://arxiv.org/pdf/1910.04260.pdf

Hochschild, Arlie Russell. 1983. The Managed Heart: Commercialization of Human Feeling. Berkeley, CA: The University of California Press.

Hoynes, Hilary, and Jesse Rothstein. Tax policy toward low-income families. No. w22080. National Bureau of Economic Research, 2016.

Hershbein, Brad, Claudia Macaluso, and Charles Yeh. 2019. "Concentration in U.S. Local Markets: Evidence from Vacancy and Data.” 2019 Meeting Paper 1336. Society for Economic Dynamics. https://economicdynamics.org/meetpapers/2019/paper_1336.pdf

Jarosch, Gregor, Jan Sebastian Nimczick, and Isaac Sorkin. 2019. “Granular Search, Market Structure, and Wages.” NBER Working Paper No. 26239.

Kleiner, Morris M. and Alan B. Krueger. 2009. “Analyzing the Extent and Influence of Occupational Licensing on the Labor Market.” Journal of Labor Economics 31(2):173-202. 
Kleven, Henrik. The eitc and the extensive margin: A reappraisal. No. w26405. National Bureau of Economic Research, 2019.

Kline, Patrick, Neviana Petkova, Heidi Williams, and Owen Zidar. 2019. "Who Profits from Patents? Rent-Sharing at Innovative Firms." Quarterly Journal of Economics 134(3):1343-1404.

Kroft, Kory, Yao Luo, Magne Mogstad, and Bradley Setzler. 2020. “Imperfect Competition and Rents in Labor and Product Markets: The Case of the Construction Industry.” NBER Working Paper No. w27325.

\author{
Krueger, Alan B. and Eric A. Posner. 2018. “A Proposal for Protecting Low-Income Workers \\ from Monopsony and Collusion.” The Hamilton Project Policy Proposal, 5. \\ https://www.hamiltonproject.org/assets/files/protecting_low_income_workers_from_monopsony \\ _collusion_krueger_posner_pp.pdf
}

Kruse, Douglas. 2016. “Does Employee Ownership Improve Performance?” IZA World of Labor. https://wol.iza.org/articles/does-employee-ownership-improve-performance/long

Lipsius, Ben. 2018. "Labor Market Concentration Does Not Explain the Falling Labor Share." Available at SSRN 3279007. https://papers.ssrn.com/sol3/papers.cfm?abstract id=3279007.

Madland, David. 2018. "Wage Boards for American Workers." Center for American Progress, April 9. 
Manoli, Day, and Ankur Patel. 2019. "Long-Term Treatment Effects of Job Search Assistance and Training: A Summary of Recent Evidence.” AEA Papers and Proceedings 109:340-343.

Marinescu, Ioana Elena, and Herbert Hovenkamp. 2018. “Anticompetitive Mergers in Labor Markets.” Indiana Law Journal 94(3):1031-1063.

Marinescu, Ioana, and Eric A. Posner. 2018. “A Proposal to Enhance Antitrust Protection Against Labor Market Monopsony.” Available at SSRN 3317575. https://papers.ssrn.com/sol3/pa pers.cfm?abstract id $=3317575$

Masakure, Oliver. 2016. “The Effect of Employee Loyalty on Wages.” Journal of Economic Psychology 56:274-298.

Matsudaira, Jordan D. 2014. "Monopsony in the Low-Wage Labor Market? Evidence from Minimum Nurse Staffing Regulations.” Review of Economics and Statistics 96(1):92-102.

McCall, J.J. 1970. "Economics of Information and Job Search.” The Quarterly Journal of Economics 84(1):113-126.

Monte, Ferdinando, Stephen J. Redding, and Esteban Rossi-Hansberg. 2018. "Commuting, Migration and Local Employment Elasticities.” American Economic Review 108(12):3855-3890. 
Naidu, Suresh. 2020. “'Essential Workers’ Are Just Forced Laborers.” Washington Post. https://www.washingtonpost.com/outlook/2020/05/21/essential-workers-pay-wages-safetyunemployment/.

Naidu, Suresh. 2010. "Recruitment Restrictions and Labor Markets: Evidence from the Postbellum U.S. South.” Journal of Labor Economics 28(2):413-445.

Naidu, Suresh, Eric A. Posner, and E. Glen Weyl. 2018. “Antitrust Remedies for Labor Market Power." Harvard Law Review 132(1): 536-601.

Naidu, Suresh, Yaw Nyarko, and Shing-Yi Wang. 2016. "Monopsony Power in Migrant Labor Markets: Evidence from the United Arab Emirates.” Journal of Political Economy 124(6):17351792.

Posner, Eric A. 2020a. "The Antitrust Challenge to Covenants Not to Compete." Antitrust Law Journal 83: 165 .

Posner, Eric A. 2020b. "The Economic Foundation of the Employee / Independent Contractor Distinction. SSRN.

Posner, Eric A. and E. Glen Weyl. 2018. Radical Markets: Uprooting Capitalism and Democracy for a Just Society. Princeton, NJ: Princeton University Press. 
Qiu, Yue, Aaron J. Sojourner. 2019. "Labor-Market Concentration and Labor Compensation.” IZA Discussion Papers, No. 12089. https://www.econstor.eu/bitstream/10419/193383/1/dp12089 $\underline{. \mathrm{pdf}}$

Rebitzer, James B., and Lowell J. Taylor. "The consequences of minimum wage laws some new theoretical ideas." Journal of Public Economics 56.2 (1995): 245-255.

Reynolds, Lloyd G. 1946. "The Supply of Labor to the Firm.” The Quarterly Journal of Economics 60(3):390-411.

Rinz, Kevin. 2018. "Labor Market Concentration, Earnings Inequality, and Earnings Mobility." Center for Administrative Records Research and Applications Working Paper 10. http s://kevinrinz.github.io/concentration.pdf

Rogerson, Richard, Robert Shimer, and Randall Wright. 2005. "Search-Theoretic Models of the Labor Market: A Survey.” Journal of Economic Literature, 43(4): 959-988.

Robinson, Joan. 1969. The Economics of Imperfect Competition. New York, NY: St. Martin’s Press.

Rothschild, Michael. 1973. "Models of Market Organization "With Imperfect Information: A Survey" Journal of Political Economy 81(6):1283-1308. 
Jäger, S., Schoefer, B., Young, S. G., \& Zweimüller, J. (2018). Wages and the Value of Nonemployment (No. w25230). National Bureau of Economic Research.

Schubert, Gregor, Anna Stansbury, and Bledi Taska. 2020. "Monopsony and Outside Options." Available at SSRN 3599454. https://papers.ssrn.com/sol3/papers.cfm?abstract id=3599454.

Schmitt, John, and Ben Zipperer. 2009. "Dropping the Ax: Illegal Firings During Union Election Campaigns, 1951-2007.” EPRN. http://www.lerachapters.org/OJS/ojs-2.4.4-

1/index.php/EPRN/article/viewFile/1875/1873.

Sokolova, Anna, and Todd Sorensen. 2018. "Monopsony in Labor Markets: A Meta-Analysis" IZA Discussion Papers, No. 11966.

Spence, Michael A. 1975. "Monopoly, Quality, and Regulation.” Bell Journal of Economics 6(2):417-429.

Starr, Evan, James J. Prescott, and Norman Bishara. 2019. "Noncompetes in the U.S. Labor Force.” University of Michigan Law \& Econ Research Paper 18-013.

Stigler, George J. 1942. "The Extent and Bases of Monopoly." The American Economic Review 32(2):1-22. 

. 1961. "Private Vice and Public Virtue." The Journal of Law \& Economics 4(Oct., 1961):1-11.

Summers, Lawrence H. 1989. "Some Simple Economics of Mandated Benefits." The American Economic Review 79(2):177-183.

Veiga, André, and E. Glen Weyl. "Product design in selection markets." The Quarterly Journal of Economics 131.2 (2016): 1007-1056.

Ward, Benjamin. 1958. "The Firm in Illyria: Market Syndicalism.” The American Economic Review 48(4):566-589.

Watson, C. Luke, and Oren Ziv. 2019. "Is the Rent Too High? Land Ownership and Monopoly Power.” https://clukewatson.github.io/files/papers/WZ_ITRTH_FULL.pdf.

Webber, Douglas A. 2015. "Firm Market Power and the Earnings Distribution.” Labour Economics 35(1):123-134.

Woodford, Michael. "Modeling Imprecision in Perception, Valuation, and Choice." Annual Review of Economics 12 (2020):13:3. 


\section{Tables}

Table 1: Labor Market Policies and Margins of Monopsony Targeted

\begin{tabular}{|c|c|c|c|}
\hline \multirow[t]{2}{*}{ Policy } & \multicolumn{3}{|c|}{ Margin of Monopsony } \\
\hline & $\begin{array}{l}\text { Raising Residual } \\
\text { Supply Elasticity }\end{array}$ & $\begin{array}{c}\text { Directly Setting } \\
\text { Wages/Compensation }\end{array}$ & Offsetting Distortion \\
\hline Wage Mandates & $\mathrm{N}$ & Y & $\mathrm{N}$ \\
\hline Antitrust: Merger Screening & Y & $\mathrm{N}$ & $\mathrm{N}$ \\
\hline Antitrust: Vertical Restraints & Y & $\mathrm{N}$ & $\mathrm{N}$ \\
\hline EITC/wage subsidy & $\mathrm{N}$ & $\mathrm{N}$ & Y \\
\hline$\underset{\text { 局ndatory Benefits }}{\text { 产 }}$ & ? & Y & $\mathrm{N}$ \\
\hline Jo & $?$ & $\mathrm{~N}$ & $\mathrm{~N}$ \\
\hline $\begin{array}{l}\text { Ligenensing } \\
\text { s. }\end{array}$ & Y? & $\mathrm{N}$ & $\mathrm{N}$ \\
\hline Trânining & Y? & $\mathrm{N}$ & Y \\
\hline 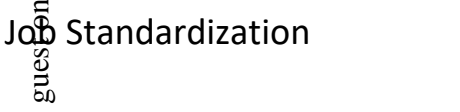 & Y & $\mathrm{N}$ & $\mathrm{N}$ \\
\hline U & Y & Y & $\mathrm{N}$ \\
\hline $\begin{array}{l}\text { Gevernance Reforms } \\
\text { J } \\
\mathbb{E}\end{array}$ & $\mathrm{N}$ & Y & $\mathrm{N}$ \\
\hline Magrcroeconomic Tightness & Y & $\mathrm{N}$ & Y \\
\hline
\end{tabular}




\section{Figures}

\section{Figure 1}

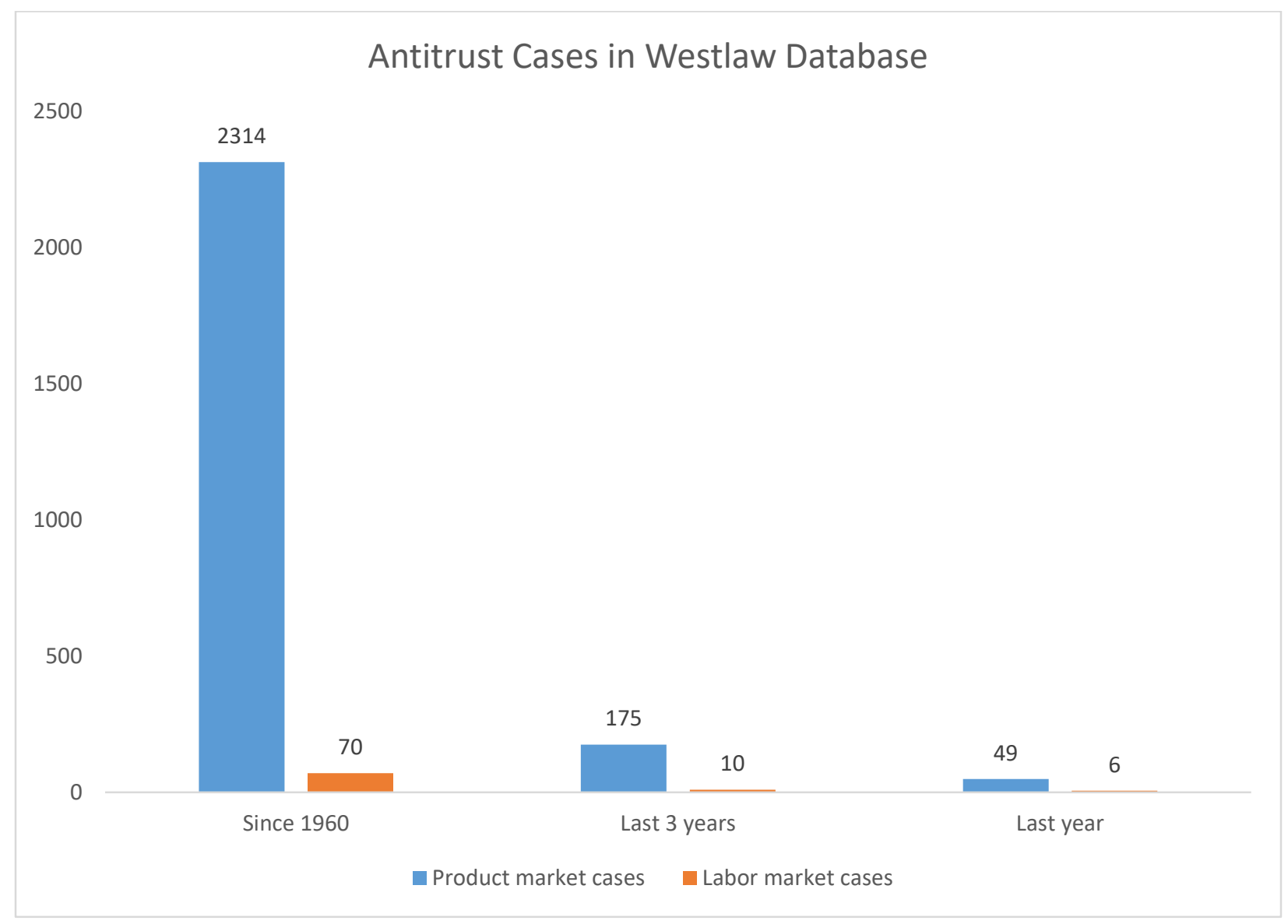

Note: based on a search of the Antitrust database in Westlaw. Searches were: “"product market' /200 (monopoly anticompetitive exclusionary)"; and "“labor market' /200 (monopsony anticompetitive exclusionary)". Searches performed on October 24, 2018. 
Figure 2

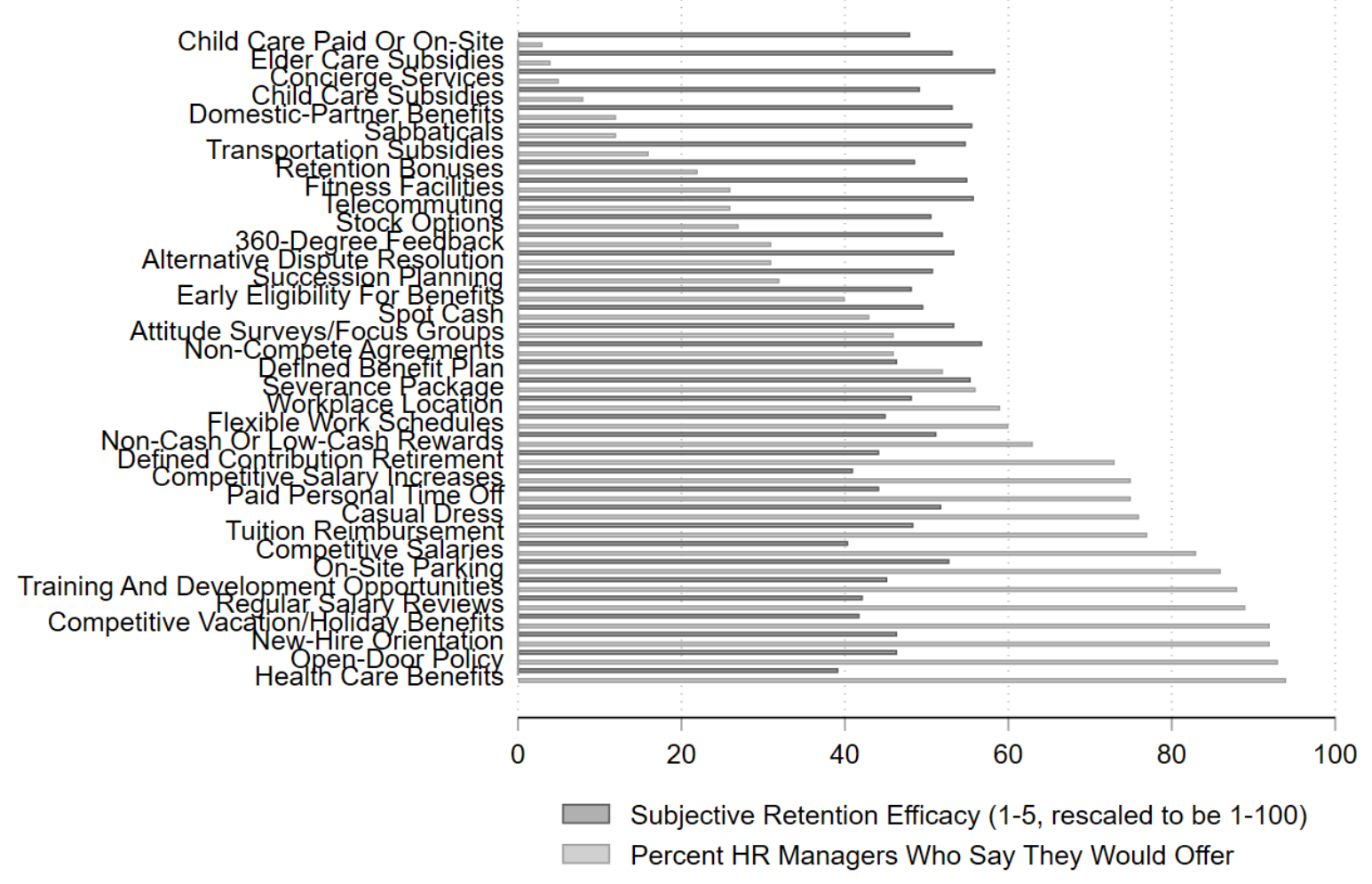

From Table 4 of 2008 SHRM Retaining Talent Report, by David Allen 
Figure 3

Firm Residual Labor Supply Elasticities/Inverse Markdowns

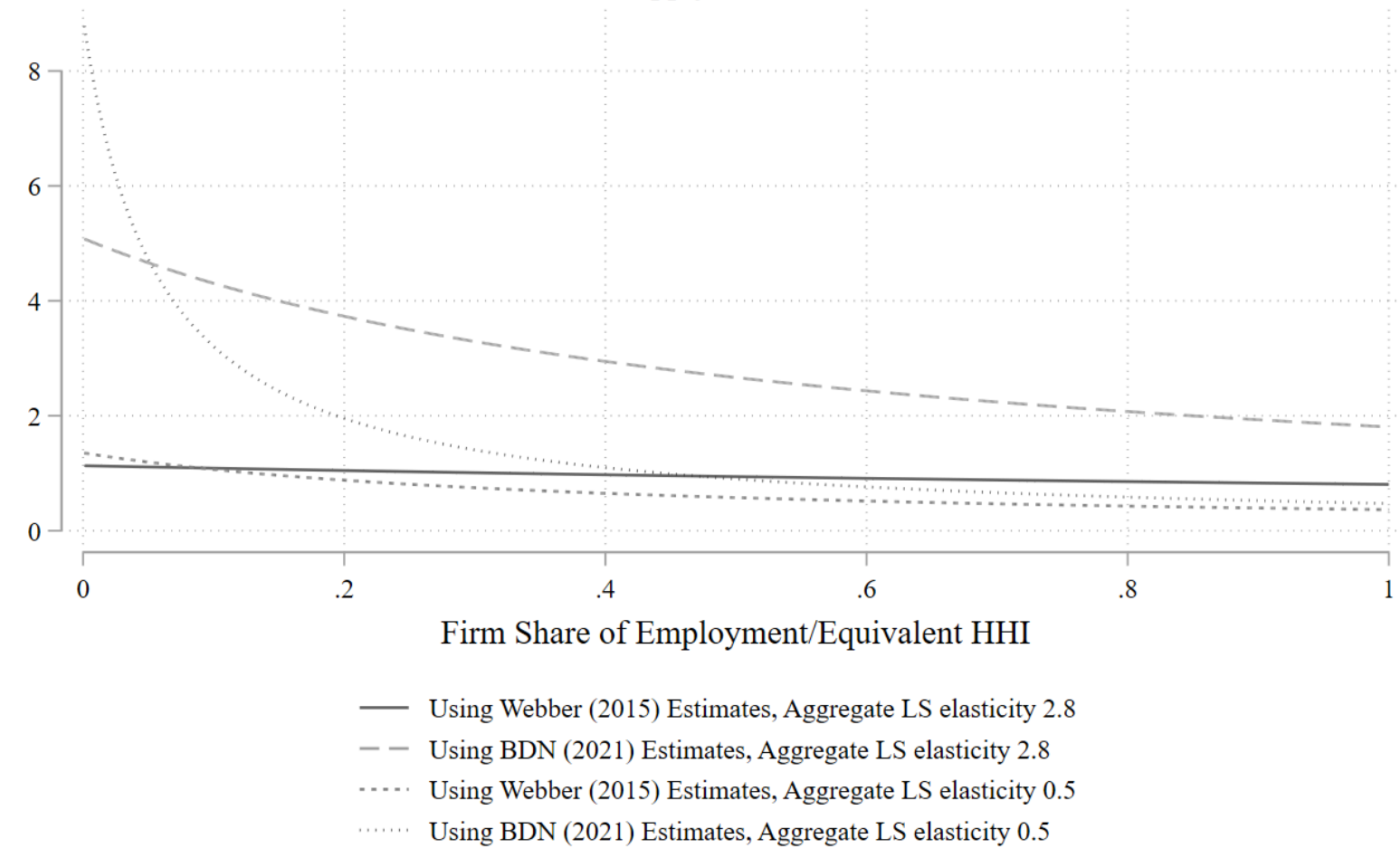

This figure shows residual labor supply elasticities as a function of firm share of employment (or HHI with equal sized firms). Residual supply elasticities are calculated as the harmonic mean of the competitive labor supply elasticity and the share-weighted aggregate supply elasticity. The competitive labor supply elasticity is estimated as described in the text using the residual labor supply elasticities reported by either Webber or BDN, along with firm-employment shares for 1000 firms drawn from a Pareto distribution with the mean and standard deviation reported in the respective paper. 
${ }^{\mathrm{i}}$ Columbia University and University of Chicago. Thanks to Nathan Wilmers and participants at the Sundance Conference for comments, and Carly Gibbons, Len Goff, and Candice Yandam for research assistance.

ii 15 U.S.C $\S 17$

iii We omit one potential source of monopsony that has been proposed but not explored empirically, adverse selection in the market for workers who want to quit, as in Acemoglu and Pischke (1998).

${ }^{\text {iv }}$ Manning (2003) discusses the difficulties of interpreting vacancy data in models of monopsony.

${ }^{v}$ A disadvantage of the Cournot model for mergers analysis is that in many cases merging parties often gain no additional profits from merging.

vi Or international but American antitrust law focuses on national effects.

${ }^{\text {vii }}$ On the matching problem in labor markets, see Naidu et al. 2018; and Caldwell and Danieli 2018.

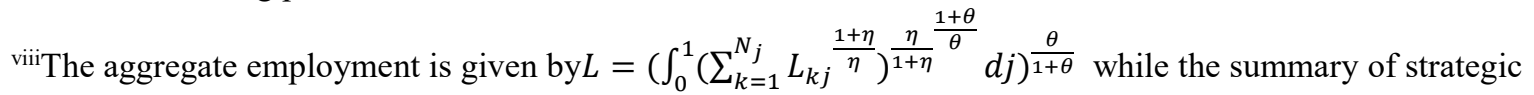

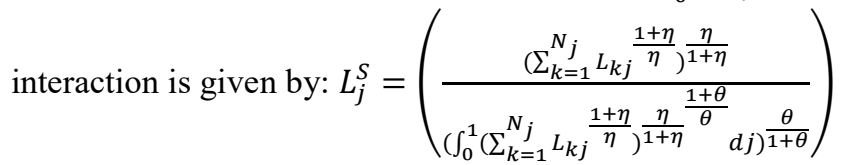

ix Recent evidence on the EITC (Kleven 2020) has put the literature (Hoynes and Rothstein 2016) in flux, as it is no longer clear that the EITC significantly increases labor force participation among affected people.

${ }^{\mathrm{x}}$ Similar arguments about raising the value of unemployment as a device to reduce monopsony power (e.g. via a UBI or wealth redistribution) could be made: in the Card et al (2016) model the residual supply elasticity is increasing in the difference between the outside option and the wage, as this goes to 0 the degree of monopsony power likewise goes to 0 .

xi $\mathrm{https://www.dol.gov/general/aboutdol/majorlaws}$

xii https://www.employmentlawhandbook.com/state-employment-and-labor-laws/illinois/

xiii Note that this implies that the usual practice in cost-benefit analysis of analyzing wage differentials across risky professions to assess the price of risks is suspect: monopsony implies that this empirical relationship only traces out the valuation for the marginal worker, not the average worker.

${ }^{\text {xiv }}$ A further distortion is theorized by Veiga and Weyl (2016), where employers may have an additional incentive to design jobs as to "cream-skim". Because labor markets are also selection markets, workplace amenities may also be structured so as to retain the most productive workers out of the set of marginal workers. Whether this results in higher or lower level of the amenity depends on the covariance of productivity with taste for the amenity among the set of marginal workers.

${ }^{x v}$ See, https://www.dol.gov/general/topic/training

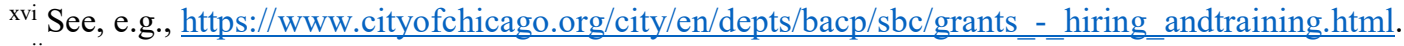

xvii This is analogous to the problem of "too many varieties" vs. "too few varieties," both of which are possible in monopolistically competitive markets as in, for example, Dixit and Stiglitz (1977).

xviii Naidu 2020. 